\title{
ANÁLISE COMPARATIVA DE ALGORITMOS DE CLASSIFICAÇÃO DIGITAL NÃO-SUPERVISIONADA, NO MAPEAMENTO DO USO E COBERTURA DO SOLO
}

\author{
Ciro Korti Matsukuma
}

Engenheiro Agrônomo

Orientador: Prof. Dr. CARLOS ALBERTO VETTORAZZI

Dissertação apresentada à Escola Superior de

Agricultura "Luiz de Queiroz", Universidade de São

Paulo, para obtenção do Título de Mestre em Ciências.

Área de Concentração: Ciências Florestais

P I R A C I C A B A

Estado de São Paulo - Brasil

Fevereiro - 2002 
MATSUKUMA, Ciro Koiti. Análise comparativa de algoritmos de classificação digital nāo-supervisionada, no mapeamento do uso e cobertura do solo.

\section{ERRATA/CORRIGENDA}

\begin{tabular}{|c|c|c|c|}
\hline p. & item & linha & onde se lê \\
\hline 7 & 2.3 & $\begin{array}{l}\text { décima } \\
\text { segunda }\end{array}$ & ...radioelétricas... \\
\hline 16 & & & $\begin{array}{l}\text {...influência do solo } \\
\text { nas áreas espectrais. }\end{array}$ \\
\hline 30 & 3.2 & terceira & $\begin{array}{l}\text {... Nos meses de } \\
\text {...(Zavatini e Cano, } \\
\text { 1993). }\end{array}$ \\
\hline 32 & 3.2 & $\begin{array}{l}\text { vigésima } \\
\text { sétima }\end{array}$ & $\begin{array}{l}\text {...Laboratório de } \\
\text { Ciências Florestais... }\end{array}$ \\
\hline 38 & 3.2 .4 & $\begin{array}{l}\text { Vigésima a } \\
\text { vigésima } \\
\text { sétima }\end{array}$ & \\
\hline 39 & 3.2 .5 & Sexta & \\
\hline
\end{tabular}

Inserir este parágrafo:...Para a construção dessa matriz foi necessário amostrar os pontos de controle. O resultado obtido foi representativo de uma parcela da área. Por meio de uma regra de três obteve-se o número de pontos total.

O módulo do IDRISI empregado foi o ERRMAT, que tabula erros de omissão e comissão, erros totais e marginais e intervalos de confiança selecionados. Também é apresentado o Îndice de Kappa de Concordância, global e por categoria mapeada.

\begin{tabular}{|c|c|c|}
\hline Tabela 4 & $\begin{array}{l}\text { décima } \\
\text { quarta }\end{array}$ & $\begin{array}{l}\text {...Exatidão de acert } \\
\text { do algoritmo... }\end{array}$ \\
\hline Tabela 5 & Sétima & $\begin{array}{l}\text {... Exatidão de acerto } \\
\text { do algoritmo... }\end{array}$ \\
\hline Tabela 6 & Sétima & $\begin{array}{l}\text {...Exatidāo de acerto } \\
\text { do algoritmo... }\end{array}$ \\
\hline Tabela 7 & Primeira & $\begin{array}{l}\text {...Exatidāo de acerto } \\
\text { do algoritmo... }\end{array}$ \\
\hline Tabela 8 & Sétima & $\begin{array}{l}\text {..Exatidão de acerto } \\
\text { do algoritmo... }\end{array}$ \\
\hline Tabela 9 & Primeira & $\begin{array}{l}\text {... Exatidão de acerto } \\
\text { do algoritmo... }\end{array}$ \\
\hline Tabela 10 & Primeira & $\begin{array}{l}\text {... Exatidāo de acerto } \\
\text { do algoritmo... }\end{array}$ \\
\hline Tabela 11 & primeira & $\begin{array}{l}\text {...Exatidão de acerto } \\
\text { do algoritmo... }\end{array}$ \\
\hline & Última & Figura 10 \\
\hline & $\begin{array}{l}\text { Terceira } \\
\text { após a } \\
\text { figura }\end{array}$ & Figura 11 \\
\hline
\end{tabular}


Dados Internacionais de Catalogação na Publicação (CIP) DIVISÃO DE BIBLIOTECA E DOCUMENTAÇÃO - ESALQ/USP

\section{Matsukuma, Ciro Koiti}

Análise comparativa de algoritmos de classificaçāo digital não-supervisionada, no mapeamento do uso e cobertura do solo / Ciro Koiti Matsukuma. - Piracicaba, 2002.

84 p. : il.

Dissertaçāo (mestrado) - - Escola Superior de Agricultura Luiz de Queiroz, 2002. Bibliografia.

1. Bacia hidrográfica 2. Mapa de uso da terra 3. Processamento digital de imagens 4. Rio Corumbatal 5. Sensoriamento remoto I. Título

CDD 631.47 
Aos meus pais e à minha esposa Ivete, dedico. 


\section{AGRADECIMENTOS}

Aos meus pais.

Ao Prof. Vettorazzi, pela orientação, amizade, atenção e paciência.

Ao SEMAE - Serviço Municipal de Água e Esgoto, pela disponibilização do material para estudo e apoio logístico.

Ao Francisco Kronka, pelo incentivo, preocupação e apoio.

À Roberta Valente pelo companheirismo, amizade e ajuda nos longos períodos no Laboratório e "passeios" no campo.

À Sandra Flörsheim, pelos momentos de descontração e pela força.

Ao Demétrio, Presidente da Comissão Editorial do Instituto Florestal.

Ao Onildo, à Nilse e ao Rui, pelas incansáveis leituras e "toques".

À Yara Cristina Marcondes, minha cunhada, pela ajuda constante.

À Marina, Andréa e Cláudia, pela amizade e ajuda incondicional.

À Margarete, Secretária do Departamento de Ciências Florestais.

Ao Geraldo, pelas horas de bate-papo nas viagens do Prof. Álvaro.

À Maria, Leni e aos colegas da Seção de Manejo e Inventário Florestal.

Ao Baitello, pelo importante apoio para a realização deste trabalho.

Ao Alberto Kazutoshi Fujihara, pela ajuda com as figuras.

Às Bibliotecárias Eliana Garcia e Silvia Zinsly, pela revisão e paciência.

À minha esposa, em especial, por suportar os momentos de ausência. 


\section{SUMÁRIO}

Página

LISTA DE FIGURAS................................................ viii

LISTA DE TABELAS..................................................... $\mathrm{x}$

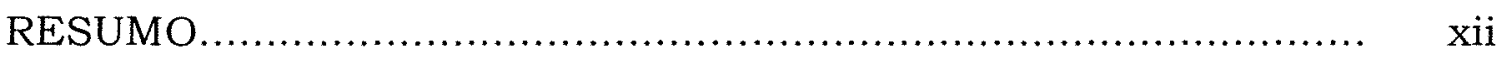

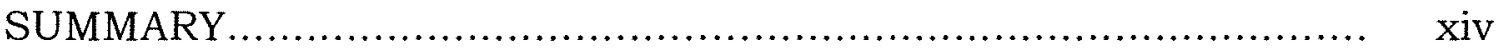

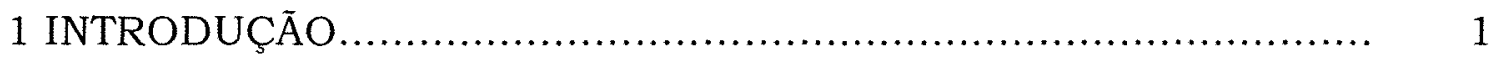

2 REVISÃO DE LITERATURA......................................... 3

2.1 Sensoriamento Remoto................................................ 3

2.2 Sistemas Sensores............................................... 5

2.3 A Imagem Digital......................................................... 7

2.4 Pré-processamento da Imagem Digital.............................. 8

2.4.1 Correção radiométrica.................................................... 8

2.4.2 Correção atmosférica................................................... 9

2.4.3 Correção geométrica.................................................. 9

2.5 Processamento da Imagem Digital................................... 10

2.5.1 Classificação Supervisionada......................................... 13

2.5.2 Classificação Não-Supervisionada.................................. 18

2.5.3 Algoritmo CLUSTER.............................................. 21

2.5.4 Algoritmo ISOCLUST.................................................. 22

2.5.5 Algoritmo MAXSET.................................................... 23 
2.6 Avaliação do Desempenho dos Algoritmos da Classificação

Digital................................................................ 24

3 MATERIAL E MÉTODOS............................................... 28

3.1 Material.................................................................. 28

3.1.1 Área de Estudo......................................................... 28

3.1.2 Equipamentos.................................................... 31

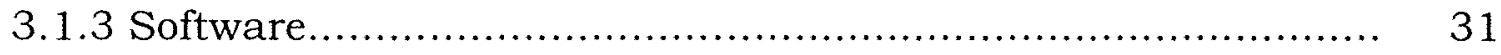

3.1.4 Bases Cartogräficas............................................... 31

3.1.5 Imagem Digital................................................... 32

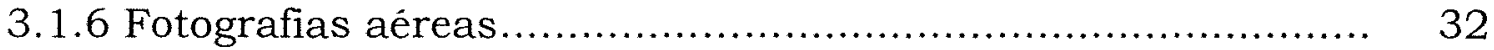

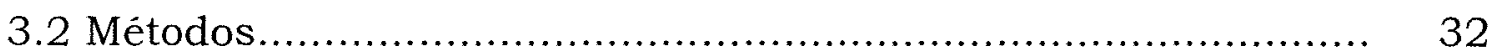

3.2.1 Delimitação da área de estudo e Definição das classes de cobertura.............................................................. 33

3.2.2 Pré-Processamento da Imagem Digital............................ 34

3.2.3 Classificação da Imagem Digital..................................... 36

3.2.3.1 Classificação Supervisionada................................... 36

3.2.3.2 Classificação Não-Supervisionada................................ 37

3.2.4 Reclassificação.......................................................... 38

3.2.5 Avaliação do Mapeamento........................................... 39

4 RESULTADOS E DISCUSSÃO ......................................... 40

4.1 Análise das matrizes de confusão e do Índice Kappa............... 61

4.2 Análise da Classificação Digital........................................ 66

5 CONCLUSÕES............................................................ 74

REFERÊNCIAS BIBLIOGRÁFICAS........................................ $\quad 75$ 


\section{LISTA DE FIGURAS}

Página

1 Localização da Bacia do Rio Corumbatai e Área deEstudo........... 29

2 Composição colorida da imagem corrigida geometricamente....... 35

3 Reclassificação das 28 subclasses após a utilização do algoritmo MAXVER........................................................................ 45

4 Reclassificação das 34 subclasses obtidas pelo algoritmo ISOCLUST.

5 Reclassificação das 28 subclasses geradas no algoritmo CLUSTER

6 Reclassificação das 60 subclasses do algoritmo MAXSET.

7 Cana-de-açúcar em relevo suave ondulado próximo à pastagem e

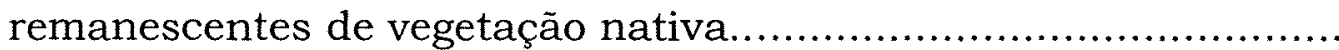

8 Cana-de-açúcar em pé e recém cortada na área de estudo evidenciando a existência de vários estados culturais.

9 Pastagem no município de Itirapina próximo a uma área com reflorestamento com sinais de erosão.

10 Horto de Rio Claro: reflorestamentos antigos de eucalipto com estrutura de floresta nativa............................................... 65

11 Área de treinamento homogênea com formato regular............. 69 
12 Áreas de treinamento de tamanho reduzido e formato

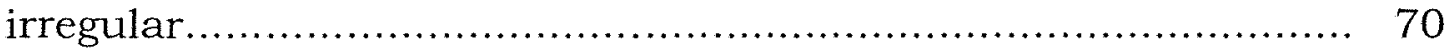

13 Métodos dos procedimentos adotados na classificação

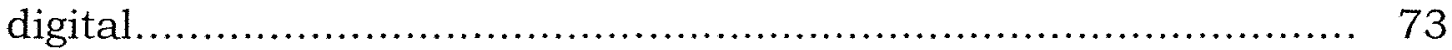




\section{LISTA DE TABELAS}

Página

1 Correspondência entre bandas e comprimentos de onda do Landsat TM e SPOT XS................................................................ 7

2 Matriz de confusão ou de erro........................................ 25

3 Qualidade do Índice Kappa, segundo sua faixa de coincidência (LANDIS \& KOCH, 1977) .......................................... 27

4 Matriz de confusão e Exatidão de acerto do algoritmo MAXVER representados em porcentagem..................................... 42

5 Matriz de confusão e Exatidão de acerto do algoritmo MAXVER com filtro de mediana $3 \times 3$ representados em porcentagem......... 44

6 Matriz de confusão e Exatidão de acerto do algoritmo ISOCLUST representados em porcentagem........................................ 47

7 Matriz de confusão e Exatidão de acerto do algoritmo ISOCLUST com filtro de mediana $3 \times 3$ representados em porcentagem......... 49

8 Matriz de confusão e Exatidão de acerto do algoritmo CLUSTER representados em porcentagem...................................... 52

9 Matriz de confusão e Exatidão de acerto do algoritmo CLUSTER com filtro de mediana $3 \times 3$ representados em porcentagem........... 54

10 Matriz de confusão e Exatidão de acerto do algoritmo MAXSET representados em porcentagem............................................

11 Matriz de confusão e Exatidão de acerto do algoritmo MAXSET com filtro de mediana $3 \times 3$ representados em porcentagem......... 
12 Índice Kappa Geral das imagens filtradas......................... 67

13 Índice Kappa Geral das imagens não filtradas...................... 67 
recomendado para utilização por ser eficiente e demandar menor tempo para obter-se a classificação final da vegetação. 
COMPARATIVE ANALYSIS OF UNSUPERVISED DIGITAL CLASSIFICATION ALGORITHMS, FOR LAND USE AND LAND COVER MAPPING

\author{
Author: CIRO KOITI MATSUKUMA \\ Adviser: Prof. Dr. CARLOS ALBERTO VETTORAZZI
}

SUMMARY

The aim of this work was to compare the classifications obtained through nonsupervised and supervised classifications algorithms applied to an area with complex landscape in the basin of Corumbataí river. Maximum Likelihood algorithm was used in ENVI software and for Idrisi software CLUSTER, ISOCLUST and MAXSET were used. The study area comprehended the districts of Piracicaba, Rio Claro, Itirapina, Analândia, Corumbataí, Charqueada and Ipeúna, SP, Brazil. Several categories were observed and classified as the following ones: sugar-cane, pasture, native vegetation, exposed soil, reforestation and urban area. After field recognition of the categories the classification was proceed by using CLUSTER, ISOCLUST and MAXSET algorithms. ISOCLUST showed better results compared to the others, being the most recommended for use due to its efficiency and less time requirement to obtain the final classification of the vegetation. 


\title{
ANÁLISE COMPARATIVA DE ALGORITMOS DE CLASSIFICAÇÃO DIGITAL NÃO-SUPERVISIONADA, NO MAPEAMENTO DO USO E COBERTURA DO SOLO
}

\author{
Autor: CIRO KOITI MATSUKUMA \\ Orientador: Prof. Dr. CARLOS ALBERTO VETTORAZZI
}

\section{RESUMO}

O objetivo deste trabalho foi comparar as classificações obtidas por meio de algoritmos de classificação não supervisionada e supervisionada, aplicados a uma região com paisagem complexa, dentro da bacia do rio Corumbataí, SP. Foram utilizados os algoritmos de Máxima Verossimilhança, no software ENVI, e CLUSTER, o ISOCLUST e o MAXSET no software Idrisi o. A imagem multiespectral utilizada foi do satélite SPOT. A área de estudo abrangeu os municípios de Piracicaba, Rio Claro, Itirapina, Analândia, Corumbataí, Charqueada e Ipeúna. Foram observadas várias categorias e classificadas, dentre elas, as seguintes: cana-de-açúcar, pasto, vegetação nativa, solo exposto, reflorestamento e área urbana. Após o reconhecimento em campo das categorias, procedeu-se à classificação utilizando-se os algoritmos Foram observadas várias categorias e classificadas, dentre elas, as seguintes: cana-deaçúcar, pasto, vegetação nativa, solo exposto, reflorestamento e área urbana. Após o reconhecimento em campo das categorias, procedeu-se à classificação utilizando-se os algoritmos CLUSTER, ISOCLUST E MAXSET, dos quais o que apresentou melhores resultados foi o ISOCLUST, sendo, portanto, o mais 


\section{INTRODUÇÃo}

O sensoriamento remoto vem sendo aplicado há décadas na observação e mapeamento da superficie terrestre, empregando vários produtos, dentre eles a fotografia aérea, a videografia aérea e imagens de satélite. A partir destes produtos é possivel extrair informaçōes sobre a cobertura e uso da terra de maneira relativamente rápida, precisa e econômica. Um exemplo é o uso das imagens orbitais, que oferecem uma visão sinóptica da área de interesse, adequada a grandes regiões. Visões mais detalhadas de uma paisagem podem ser obtidas a partir de fotografias aéreas ou de sistemas de video aerotransportados (Lachowski et al., 1994).

Para a classificação de imagens digitais, com a finalidade de mapeamento da superficie terrestre, são usados métodos visuais ou aplicados "softwares" de tratamento de imagens remotas, que se utilizam de algoritmos de classificação digital. Este processo agiliza a obtenção de informações e resultados, porém ainda prescinde de intervenção humana.

Os vários algoritmos existentes para classificação digital de imagens diferem entre si quanto à complexidade e ao desempenho e, ainda, para um mesmo algoritmo, os resultados podem ser diferentes em função de algumas variáveis, como por exemplo o relevo da área de estudo, que pode influenciar o uso e cobertura da terra. 
O emprego da classificação digital supervisionada em paisagens heterogêneas requer um número grande de amostras de treinamento para o algoritmo de classificação.

Como forma de agilizar o processo de classificação digital, pode-se utilizar os algoritmos não-supervisionados, que não necessitam de amostras de treinamento. Os resultados da utilização desses algoritmos podem, após adequada verificação da verdade terrestre e reclassificação, ser empregados como mapas finais de uso e cobertura da terra. Pode também servir ao direcionamento da extração de amostras de treinamento para o que se convencionou chamar de método híbrido de classificação digital.

Portanto este trabalho tem como objetivo principal verificar a possibilidade de substituir a classificação supervisionada pela classificação digital não-supervisionada no mapeamento do uso e cobertura da terra, em uma paisagem heterogênea. Para atingir este objetivo, serão analisados e comparados os desempenhos de alguns algoritmos de classificação digital não-supervisionada e supervisionada com imagens filtradas e não-filtradas, em parte da Bacia do Rio Corumbataí. 


\section{REVISÃO DE LITERATURA}

\subsection{Sensoriamento Remoto}

Nas últimas décadas, o desmatamento tem sido um problema sério. O monitoramento da superficie da terra fez-se necessário para a administração desse problema. O sensoriamento remoto é uma boa ferramenta para o monitoramento de mudanças ambientais (Jusoff e Manaf, 1995).

Novo (1992) define sensoriamento remoto como a aquisição de informações sobre objeto sem contato direto e registro da energia proveniente e apresentação em formato adequado à extração de informações.

Segundo Campbell (1996), um elemento essencial para o sensoriamento remoto é a geração da imagem superficial da terra. Uma das maneiras de fixar a imagem por processos químicos é a fotografia, podendo ser realizada no nivel do solo em aviões ou até mesmo do espaço. Para extrair as informações contidas nas fotografias foi desenvolvida a aerofotogrametria, que permite medição precisa dos objetos em solo. Outros usos foram dados para esta técnica, como planejamento, geologia, mapeamento de florestas e estatísticas agrícolas.

Em 1972, com o lançamento do satélite Landsat-1, teve início a rotina de utilização de imagens orbitais para o estudo da superficie terrestre, tendo sido desenvolvidos a partir de 1990, sensores 
hiperespectrais que captam a radiação eletromagnética de maneira quase que contínua ao longo do espectro eletromagnético utilizável.

Ainda segundo Campbell (1996), a utilização das imagens LANDSAT expandiu o uso da análise digital, antes realizada completamente por meios visuais.

A interpretação das imagens LANDSAT, através das características multi-espectrais, pode oferecer informações precisas para o monitoramento de áreas de proteção e conservação com características heterogêneas e com alto volume de problemas, uma vez que é possivel a obtenção de novas informações em curto espaço de tempo, sendo portanto, uma ferramenta útil na tomada de medidas para a proteção da natureza (Santos, 1982).

No entanto, Kuplich (1994) observou a complementaridade entre produtos "Synthetic Aperture Radar" (SAR) do satélite ERS 1 e imagens "Thematic Mapper" (TM) do satélite LANDSAT-5. Os resultados foram confirmados através de estatística Kappa e apontam melhoras significativas na classificação quando utilizadas componentes principais do registro das bandas TM e SAR filtradas para as classes de Área urbana, Pastagem e Reflorestamento. A complementaridade foi observada principalmente para os alvos urbanos, onde as áreas construídas são evidenciadas na resposta do "Radio Detection and Ranging" (RADAR). Para as imagens de radar deve-se ressaltar a importância da filtragem para redução do "speckle" (ruîdo de aparência granular inerente a este tipo de sensor). Essa complementaridade se torna evidente quando consideramos os sensores óticos sujeitos às condiçōes atmosféricas, principalmente em regiōes tropicais, com variações atmosféricas de área e sazonais, que dificultam o monitoramento dos recursos da superficie terrestre. 


\subsection{Sistemas Sensores}

Qualquer equipamento capaz de transformar alguma forma de energia proveniente do ambiente em informação constitui-se num sistema sensor (Novo, 1992). Esses equipamentos podem ser divididos em: a) sensores passivos, que detectam a radiação proveniente da reflexão da luz solar sobre objetos da superficie, ou seja, dependem de uma radiação externa para a sua operação, e sensores ativos, que tem a sua própria fonte de radiação. Os sensores passivos operam na faixa do visivel infravermelho próximo e infravermelho médio, e os sensores ativos operam na faixa de microondas; e b) sensores ativos que utilizam a emissão de radiação eletromagnética na faixa das microondas situando-se entre o infravermelho e as ondas de rádio $(0,3-300 \mathrm{GHz})$ e sensores para captar parte da radiação refletida. Dentre os satélites comerciais que operam com esse sistema podemos citar o ERS-1, sendo particularmente úteis em regiões onde há cobertura de nuvens na maior parte do tempo, operando também à noite. Devido a interações das microondas com os componentes atmosféricos são gerados muitos ruídos. Há a necessidade de várias filtragens para que as imagens possam ser utilizadas necessitando de recursos computacionais mais robustos.

Nos sistemas passivos, as radiações eletromagnéticas refletidas na superficie são provenientes do sol. Devido às caracteristicas dos gases que compõem a atmosfera, grande parte da radiação é absorvida e apenas algumas freqüências, que estão na região do visível e infravermelho, podem ser captadas.

Existe um grande número de satélites que utilizam sistemas passivos, disponiveis para uso civil, entre os mais conhecidos estão os satélites da série SPOT e LANDSAT. Os satélites da série SPOT 
têm como principal característica a maior resolução espacial, sendo de $20 \mathrm{~m}$ para o modo multiespectral e de $10 \mathrm{~m}$ para o pancromático. A série de satélites LANDSAT tem como principal característica a resolução espectral, que varia desde a região do visível até o infravermelho, incluindo o infravermelho termal.

O SPOT 4 tem caracteristica de construção de seus sensores para a deteç̧ão da radiação eletromagnética semelhante ao do LANDSAT-5, abrangendo as regiōes do visivel do infravermelho próximo e do infravermelho médio. Diferem, porém, no intervalo de detecção (Tabela 1). Para o satélite SPOT 4, as imagens são obtidas por uma matriz de detectores dispostos linearmente, em sentido perpendicular ao deslocamento, obtendo uma leitura instantânea de uma faixa de terreno, detectando a radiação eletromagnética em quatro faixas espectrais. A junção dessas faixas no transcorrer de sua órbita, forma uma cena, que sofre influência dos movimentos do satélite. Assim, quando se obtém a imagem completa, deve-se ajustá-la para reduzir a distorção inerente ao processo de imageamento. O satélite LANDSAT 5 utiliza um espelho rotativo que direciona a luz proveniente da Terra para um conjunto de detectores. Este satélite opera em sete faixas espectrais, necessitando de um ajuste para a formação de uma imagem ao longo de sua órbita (Novo, 1992). 
Tabela 1. Correspondência entre bandas e comprimentos de onda do Landsat TM e SPOT XS.

\begin{tabular}{ccccccc}
\hline BANDAS & TM1 & TM2 & TM3 & TM4 & TM5 & TM7 \\
\hline$\mu \mathrm{m}$ & $0,45-0,52$ & $0,52-0,60$ & $0,63-0,69$ & $0,76-$ & $1,55-$ & $2,08-2,35$ \\
& & & & 0,90 & 1,75 & \\
\multirow{2}{*}{ BANDAS } & $\mathrm{X} 1$ & $\mathrm{X} 2$ & $\mathrm{X3}$ & $\mathrm{X} 4$ & \\
$\mu \mathrm{m}$ & & $0,50-0,59$ & $0,61-0,68$ & $0,79-$ & $1,58-$ & \\
& & & & 0,89 & 1,75 & \\
\hline
\end{tabular}

\subsection{A Imagem Digital}

Formalmente, uma imagem é uma função bidimensional da intensidade de luz refletida ou emitida por uma cena, representada por $f(x, y)$, onde os valores de $f$ a cada coordenada espacial $(x, y)$ dão a intensidade da imagem nesse ponto (Dutra et al., 1981 e Quintanilha, 1990). Essa intensidade é numericamente representada na imagem por um valor inteiro não-negativo e finito, chamado nivel de cinza. A área no terreno representada por um "pixel" é definida pela altitude e caracteristica do sistema sensor - "Instantaneous Field of View" (IFOV) ou campo instantâneo de visada, que representa o ângulo submetido pela projeção geométrica de cada detetor na superficie do terreno. Uma imagem digital é formada pelas suas informações espaciais, espectrais e radioelétricas. Além disso, uma imagem registra informações em um determinado momento. Assim, devido a variações temporais, podem-se extrair diferentes informações de imagens de uma mesma área, obtidas em diferentes épocas. 


\subsection{Pré-Processamento da Imagem Digital}

Os satélites de sensoriamento remoto são plataformas contendo sensores que captam a radiação eletromagnética proveniente da reflexão da luz pela superficie terrestre. Esse dispositivo de aquisição de dados orbita a Terra e sofre a influência da gravidade e da alta atmosfera, sendo necessário monitorar sua altura e movimentos, corrigindo-os para que operem conforme foi projetado.

Dependendo dos objetivos do trabalho e das condições em que se encontra a cena utilizada, devem ser feitos pré-processamentos que servem para corrigir erros sistemáticos. Portanto, em diferentes tipos de imagens, dependendo da forma como elas são obtidas e transformadas, o aparecimento de distorções pode ser de tal magnitude que se faça necessário corrigi-las ou minimizar seu efeito antes de se efetuar os procedimentos computacionalmente idealizados para melhorar a sua qualidade visual e corrigir erros de posicionamento. Nesse sentido, utilizam-se as técnicas de correção geométrica, radiométrica e atmosférica.

\subsubsection{Correção Radiométrica}

De acordo com Novo (1992), "a função dos programas de correção radiométrica é minimizar diferenças entre os níveis de cinza registrados por uma matriz de detectores". Este procedimento envolve a transformação da resposta original do detector numa resposta linear, porém, qualquer técnica de correção radiométrica altera os dados originais, podendo levar à degradação do sinal original. 


\subsubsection{Correção Atmosférica}

Muitas vezes se faz necessário o uso da correção atmosférica, com o objetivo de reduzir os efeitos provenientes da interferência da atmosfera sobre os valores dos niveis de cinza. Segundo Novo (1992), existem métodos para a correção atmosférica que exigem dados de radiossondagem para o cálculo e que nem sempre estão disponiveis. Existem métodos simplificados de correção atmosférica que baseiam-se na suposição de interferência aditiva da atmosfera. Desta forma, utilizam-se pontos como lagos com água limpa e sombras, onde a radiância teoricamente é nula, sendo então o valor medido nesses pontos atribuído à interferência atmosférica, onde o valor de nível de cinza é subtraído de toda a cena.

\subsubsection{Correção Geométrica}

As imagens de satélite contêm várias distorções geométricas inerentes ao método de aquisição da imagem e a órbita do satélite e devem receber um tratamento que as oriente em função de coordenadas e projeções cartográficas mais adequadas à região estudada.

Segundo Crosta (1992), a correção geométrica de uma imagem pode ser realizada a partir de um mapa plani-altimétrico confiável. Nesta base serão definidos pontos de controle que possam ser localizados também na imagem, podendo ser utilizado o "Global Positioning Systems" (GPS) para locais onde não existam mapas.

A correção geométrica, segundo Novo (1992), pode ser

obtida pela reamostragem de pixels de uma determinada cena onde 
haverá a reformatação segundo uma dada base cartográfica. A reamostragem realoca o pixel em sua nova coordenada, sendo que o seu nivel de cinza pode ser determinado por uma das técnicas: alocação de vizinho mais próximo onde não há alteração dos valores de cinza originais, interpolação bilinear ou convolução cúbica.

\subsection{Processamento da Imagem Digital}

As técnicas de processamento de imagem dentro de um Sistema de Informações Geográficas são uma ferramenta favorável, uma vez que permite o tratamento de dados e gera parâmetros adicionais aos métodos já convencionais de pesquisa (Ferreira, 1992).

Segundo Crosta (1992), o processo de classificação consiste em atribuir cada pixel de uma imagem a uma dada classe, assumindo que o conjunto de classes foi previamente determinado, tendo suas propriedades bem conhecidas. O problema da classificação é a simplificação de inúmeras variáveis encontradas nas superficies reais, o que leva à necessidade de verificar outras fontes com dados conhecidos.

Existem basicamente duas abordagens para classificação de imagens multiespectrais, que são a classificação supervisionada, onde pixels das classes pré-determinadas são localizados na imagem e submetidos ao algoritmo de classificação e a classificação nãosupervisionada, onde o algoritmo agrupa os pixels em classes espectrais e, posteriormente, é feita uma reclassificação com base em dados de campo.

Segundo Lillesand \& Kieffer (1994), o objetivo global dos algoritmos de classificação de imagens orbitais é classificar todas as 
categorias de cobertura da terra, ou temas, automaticamente, podendo ser supervisionados ou não-supervisionados. No primeiro caso, o analista deve especificar para o algoritmo uma descrição numérica dos vários tipos de cobertura da terra presentes em uma cena, delimitando pixels de locais onde a cobertura é conhecida, o que são as chamadas "amostras de treinamento". Os vários pixels da imagem são então classificados segundo os parâmetros estatísticos para cada categoria. $\mathrm{Na}$ classificação não-supervisionada o algoritmo agrega os pixels em agrupamentos naturais presentes na cena. Posteriormente, o analista determina a qual categoria pertence cada agrupamento.

A grande maioria dos modelos desenvolvidos para a análise de dados de Sensoriamento Remoto pressupõe que o alvo tenha comportamento lambertiano e que se localize numa superficie plana, horizontal, uniformemente iluminada, condição que não corresponde às encontradas na natureza. O relevo é geralmente variável e interfere na irradiância sobre a superficie, causando diferentes intensidades em função de sua exposição em relação à fonte de radiação eletromagnética. O ângulo de visada do sensor também é alterado, fato que seria irrelevante se os alvos fossem isotrópicos, mas os mesmos são anisotrópicos, causando alterações na intensidade de energia detectada pelo sensor (Novo, 1992).

A utilização de algoritmos de classificação digital da cobertura da terra não é um processo perfeito, o que pode levar a estimativas equivocadas sobre a cobertura de diversas categorias de uso. O problema pode ser reduzido com a utilização de técnicas de calibração estatística (Czaplewski, 1994).

A variedade de sensores imageadores, com diversas resoluções espaciais e espectrais, tem auxiliado na avaliação de toda a superficie do solo. As imagens orbitais são mais uma forma, além da 
fotografia aérea, de obtenção de informações da superficie terrestre. Cada tipo de produto, seja fotografia aérea ou imagem de satélite, tem suas vantagens e limitações específicas. A interpretação visual é a forma mais usual na maioria dos estudos de sensoriamento remoto, freqüentemente com surpreendente exatidão. As técnicas digitais são baseadas, de modo geral, em medições em cada pixel e dentro de um contexto, sendo as análises de textura pouco sofisticadas (Thompson e Whitehead, 1992).

Nascimento \& Almeida Filho (1996) concluíram que a dimensão das classes temáticas influencia o desempenho da técnica da segmentação, módulo existente no software SPRING, desenvolvido pelo INPE, que agrupa pixels por similaridade, a partir de um "pixelsemente", e à medida que a diferença das dimensões entre classes aumenta, maior é a dificuldade em escolher o par de limiar adequado. A técnica da segmentação apresentou um resultado satisfatório, substituindo várias etapas da interpretação visual, restando ao especialista a associação das classes temáticas aos polígonos criados pelo segmentador.

O estudo de Caetano et al. (1997) mostra que a classificação tradicional de imagens de satélite, pixel-a-pixel, não explora completamente as informações contidas em uma imagem. Operadores contextuais, que foram desenvolvidos para identificar usos específicos da terra, os quais não podem ser identificados na análise pixel-a-pixel, tiveram êxito identificando determinadas classes de cobertura de terra. Exemplos desses algoritmos foram aqueles desenvolvidos para a discriminação de áreas residenciais, com base na abundância e arranjo espacial dos alvos.

Além dos algoritmos supervisionados e não supervisionados existem técnicas complementares como a existente no 
software SPRING, que utiliza a técnica do fatiamento, que divide a imagem em áreas homogêneas, onde serão aplicadas as técnicas tradicionais. Alves et al. (1998) utilizaram as técnicas de fatiamento da banda 5 do Landsat-5 e classificação supervisionada e não supervisionada nas bandas 3, 4 e 5 . A área de estudo foi a floresta tropical em Rondônia, onde foram realizados levantamentos do desflorestamento. Nenhuma das técnicas apresentou vantagens ou desvantagens em relação às outras, apresentando todas, um excelente grau de concordância, com o índice Kappa variando de 0,833 a 0,885. Nos casos onde o classificador exige a interferência do analista os resultados podem ser melhores, contudo exige do analista conhecimento mais profundo do problema a ser tratado. Para maiores volumes de dados haveria necessidade de um número maior de especialistas com alto grau de especialização.

\subsubsection{Classificação Supervisionada}

Este método supõe que a nuvem de pontos (valor dos pixels de determinada classe) tem distribuição normal em torno da média e que o padrão de resposta pode ser totalmente descrito por meio de um vetor e de uma matriz de covariância. Com esses dados, pode ser calculada a probabilidade estatística de um determinado valor de pixel pertencer a uma determinada categoria de cobertura da terra (Eastman, 1997).

Segundo Crosta (1992), para que a classificação por Máxima Verossimilhança (MAXVER) seja precisa o suficiente, é necessário um número razoavelmente elevado de pixels para cada amostra de treinamento, número esse preferencialmente acima de uma 
centena. Esse número permite uma base segura para tratamento estatístico. Sendo N o número de bandas empregadas na classificação, Swain e Davis (1978) recomendam um número mínimo de $10 \mathrm{~N}$ pixels para a amostra de treinamento de cada classe espectral, sendo $100 \mathrm{~N}$ altamente desejável, se este número puder ser obtido.

Fonseca (1995) utilizou a classificação supervisionada para avaliar a classificação digital no Núcleo Picinguaba do Parque Estadual da Serra do Mar (SP). Relatou a necessidade de se reduzir a interferência atmosférica dada a necessidade de conhecimentos suplementares para enfrentar o problema. O processo de classificação supervisionada depende da capacidade do intérprete em reconhecer as classes na imagem e de sua experiência com a área em questão. O resultado da classificação não correspondeu às expectativas. Aspectos, como o sombreamento e a orientação de vertentes, interferiram de forma determinante na classificação e, quanto à vegetação, os resultados foram piores onde esta apresentava-se mais conservada.

Caldeira (1994) concluiu que o classificador supervisionado de Máxima Verossimilhança (MAXVER), aplicado à região de Itaoca, Espírito Santo, com imagens LANDSAT, apresentou melhores resultados quando recebeu o apoio de uma classificação não-supervisionada, utilizando um classificador de K-médias. Este processo utiliza a classificação supervisionada e não supervisionada e é chamado de classificação híbrida. Para a determinação visual das áreas de treinamento na imagem, as melhores combinações foram as bandas 3,4 e 5. Deve-se destacar que a definição das classes a serem mapeadas pode influir no sucesso do trabalho, e nem sempre os alvos escolhidos são espectralmente diferenciáveis.

Brites et al. (1996) aplicaram o algoritmo MAXVER, existente no sistema IDRISI, para três combinaçōes de três bandas do 
sensor TM do LANDSAT-5 com o intuito de avaliar a exatidão da estratégia de amostragem por meio do índice Kappa. Observaram que, dependendo da estratégia de amostragem, os índices de exatidão podem ser superestimados. É importante mencionar qual foi a estratégia utilizada, caso contrário, o índice pode não estar representando a exatidão esperada.

Medeiros et al. (1996), trabalhando com imagens LANDSAT, utilizaram o algoritmo MAXVER e verificaram grandes diferenças entre as estimativas obtidas pela imagem do satélite e as estimativas do Levantamento Sistemático da Produção Agrícola (LSPA), para os dados de cana-de-açúcar, soja e milho.

Hernández-Filho et al. (1998) compararam imagens TM/LANDSAT E HRV/SPOT em duas épocas do ano para mapeamentos fitofisionômico e de uso da terra de parte da Bacia do Alto Taquari (MS). As imagens foram interpretadas visualmente com a finalidade de identificar itens como: campo, cerrado, áreas agrícolas, espelho d'água, etc. Utilizaram também o algoritmo de classificação MAXVER, que não apresentou um desempenho satisfatório no mapeamento fitofisionômico e de uso da terra na área de estudo quando comparado à interpretação visual. A avaliação dos desempenhos entre os produtos utilizados mostrou ligeira superioridade dos produtos HRV/SPOT em relação aos produtos TM/LANDSAT.

Crosta (1992) comenta que o algoritmo MAXVER, bem como outros algoritmos de classificação supervisionada, parte do princípio de que o usuário tem profundo conhecimento da imagem a ser classificada para poder definir classes que sejam representativas. Devem contar também com observações de campo para o levantamento da "verdade terrestre". Nos casos em que isso não ocorre, é possível partir de algumas premissas razoáveis para permitir bons resultados. 
Porém, é bastante provável que, na maioria dos casos, existam tipos de superficies ou coberturas que o operador não consiga perceber visualmente, devido a diferenças sutis em suas propriedades espectrais. Quando isto ocorre, segundo o autor mencionado, nenhuma das técnicas supervisionadas será capaz de reconhecer essas coberturas como classes.

Segundo Chen (1988) "para estudar a separação de multiculturas de verão em paises tropicais, mais esforços devem ser dispendidos devido à heterogeneidade das respostas espectrais dos diversos alvos agricolas no campo e à baixa possibilidade de utilizar uma análise temporal". Para esse estudo foi utilizada uma imagem TM/LANDSAT de 19/01/85, bandas 2,4 e 5, nas estimativas de culturas de verão para o ano de 1985 em duas áreas do Estado do Paraná. Foram detectadas culturas de milho, algodão, soja e cana-deaçúcar. O algoritmo utilizado foi o MAXVER, sendo encontrados erros na classificação, principalmente, nas áreas de treinamento ou de testes, onde a influência do solo nas áreas espectrais das culturas foi maior. Para análise unitemporal, seria apropriado conhecer a época de colheita das diversas culturas, com o intuito de evitar confusão na classificação (Chen, 1988).

Dias et al. (1988) estudaram o efeito topográfico para reflorestamentos em regiōes montanhosas. Nesse trabalho, os autores supuseram que o comportamento de reflexão de uma floresta é Lambertiano. Foram utilizadas as bandas 3,4 e 5 do LANDSAT/TM. Estas bandas foram classificadas por meio do algoritmo MAXVER aplicado sobre uma imagem bruta e outra com correção do efeito topográfico. Concluíram que visualmente há uma melhora na classificação após a correção. 
Assunção e Duarte (1983) trabalharam na determinação de áreas preparadas para o plantio utilizando fotografias aéreas e dados do sensor MSS do satélite LANDSAT. Observaram similaridade de respostas espectrais entre os temas citros e cana-de-açúcar nova com o tema solo preparado para plantio (solo exposto arado ou gradeado), justificando esse fato pela pouca cobertura que os pomares e o cultivo de cana-deaçúcar recém instalado exercem sobre o solo.

Com respeito a identificação e mapeamento de culturas agricolas no Brasil, Chen (1988) afirmou que as culturas de verão são muito mais complexas do que as de inverno, devido à heterogeneidade de respostas espectrais. O Autor afirmou que essa complexidade pode ser contornada usando uma análise multi-temporal; porém, que a indisponibilidade de dados dos sensores óticos, causada pela alta porcentagem de cobertura de nuvens nas imagens durante o verão, dificulta a sua aplicação. Chen et al. (1986) analisaram critérios de discriminação das culturas de soja, milho e cana-de-açúcar a partir de dados do sensor TM/LANDSAT. Observaram que as matrizes de classificação ao se usar as bandas 2,4 e 5 foram similares às resultantes da classificação com as bandas $2,4,5$ e 7 .

Batista et al. (1978) observaram para uma região de Ribeirão Preto (SP), que os dados MSS/LANDSAT, obtidos no mês de julho, para a discriminação de áreas com cana-de-açúcar, foram mais propícios para a avaliação dessa cultura que aqueles obtidos em fevereiro ou março. Destacaram que fatores relacionados com a própria cultura tais como: estádio de desenvolvimento; época de plantio e colheita; e variedade afetaram decisivamente o seu comportamento espectral e, conseqüentemente, a exatidão da identificação e avaliação de sua área a partir dos dados de sensoriamento remoto. 
Formaggio e Epiphanio (1990) relatam que em termos de sensoriamento remoto, determinadas fases da agricultura são caracterizadas por lentas mudanças espectrais, como por exemplo o período que vai da primeira gradagem, após a colheita, até o plantio seguinte, ou mesmo o período que vai da fase de completa cobertura da terra até a fase de pré-amadurecimento. Essas fases são caracterizadas por suaves alterações de reflectância. Por outro lado, há fases no processo agricola que alteram rapidamente o comportamento espectral, tais como aquelas determinadas pelo aparecimento e desaparecimento da cultura numa dada área.

A comparação de resultados de classificação entre uma imagem LANDSAT TM e uma imagem do SPOT4 mostrou que não havia diferença significativa entre ambos, exceto quando a classificação nãosupervisionada era usada. Desde que a aproximação de classificação é influenciada pela banda selecionada no processo, e levando-se em consideração que a resolução espectral da imagem LANDSAT TM é maior, houve uma melhor separação das classes, produzindo então, classificações com exatidão mais alta (San Miguel-Ayánz e Biging, 1997).

\subsubsection{Classificação Não-Supervisionada}

A classificação não-supervisionada baseia-se no princípio que os algoritmos são capazes de identificar classes dentro do conjunto de pixels da imagem (Crosta, 1992). No espaço de atributos são formados agrupamentos, que serão utilizados como amostras de treinamento.

Para a utilização de um algoritmo de classificação nãosupervisionado, é necessário fornecer parâmetros que indicam o limite 
entre uma categoria e outra, estabelecido pelo usuário que interage com o software, apenas neste momento (Crosta, 1992).

A classificação não-supervisionada dispensa o conhecimento prévio da área de estudo por parte do analista, sendo uma vantagem a ser considerada em relação à classificação supervisionada (Novo, 1992).

Vogelmann et al. (1998) obtiveram informações sobre uma ampla área de cobertura da terra a fim de subsidiar projetos de satélites de defesa, meteorológicos, censo da população, planejamento ambiental, política de desenvolvimento, padrões espaciais de biodiversidade etc. Devido à enorme extensão da área de interesse, a utilização das técnicas tradicionais, desenvolvidas para pequenas áreas, não se mostrou adequada para este fim. Assim, foi utilizada a classificação não-supervisionada em um mosaico de imagens, obtendo primeiramente 100 classes espectrais. Posteriormente, com auxilio de fotografias aéreas, essas classes foram agrupadas em 15 categorias de cobertura da terra. Para auxiliar o estabelecimento das classes, foram utilizadas outras fontes de informação como bibliografia, verificação de campo e interpretação de fotos aéreas.

Jusoff e Manaf (1995) utilizaram dados do LANDSAT TM, do periodo de 1988 a 1991, para monitorar o desmatamento em uma reserva florestal na Malâsia. Para o processamento digital da imagem TM foi utilizado o IDRISI. Utilizou-se a classificação não-supervisionada em uma composição colorida das bandas 3,4 e 5 . Os resultados permitiram uma exatidão de $90 \%$ para os valores da taxa de desmatamento.

Ferreira (1992), aplicando o algoritmo ISODATA ("Iterative Self-Organizing Data Analysis Technique"), em uma imagem LANDSATTM 5, obteve resultados preliminares que mostraram razoável 
correlação geológica, sendo que as discrepâncias encontradas podem ser amenizadas através de outros parâmetros, como a utilização de imagens de radar. Para a melhoria da classificação, recomenda-se a utilização da classificação híbrida, que consiste na utilização da classificação não-supervisionada, (ISODATA), que fornecerá subsídios para a seleção de amostras de treinamento de uma classificação supervisionada.

Ipolliti-Ramilo (1999) utilizou as classificações supervisionada e não-supervisionada para a previsão da área de culturas de verão, na região de Campinas, SP. As culturas consideradas no estudo foram algodão, batata, feijão, milho, tomate e, predominantemente, cana-de-açúcar. Porém, a discriminação de um número limitado de situações mostrou ambigüidades nas faixas espectrais do vermelho e infravermelho do espectro eletromagnético. Nas épocas de predominância do cultivo de cana-de-açúcar ocorreu ambigüidade com as culturas de ciclo curto no verão. Para resolver essas confusões foi imprescindivel o uso dos dados do mês de junho. Ficou patente a importância do conhecimento da região de estudo pelo analista, possibilitando a melhor identificação do uso da terra com as classificaçōes. Nesse aspecto, bases de dados históricos georreferenciados dos usos agrícolas da região podem suprir a sua falta, sendo utilizados para atribuição dos usos prováveis, segundo a época de plantio e utilização das terras em verões anteriores.

Alves et al. (1996) utilizaram uma técnica de segmentação de imagens, presente no sistema "SPRING" baseada no crescimento de regiões e no uso de um classificador não-supervisionado. A técnica busca delimitar áreas, utilizando uma combinação de bandas de imagens. Concluiram que os resultados gerais foram satisfatórios, 
apresentando bom potencial para a geração de mapas de cobertura da terra de forma mais rápida que a convencional.

Dentre os algoritmos de classificação não-supervisionados o "ISOCLUST" (ou ISODATA), é o algoritmo mais adotado. Jusoff e Manaf (1995) consideraram como uma boa ferramenta para a análise de monitoramento de mudanças ambientais entre periodos.

Os diferentes algoritmos de classificação nãosupervisionada estão descritos abaixo, segundo Eastman (1997).

\subsubsection{Algoritmo CLUSTER}

O algoritmo CLUSTER procura os picos nos casos onde a freqüência é mais alta que a de seus vizinhos imediatos em qualquer lado. No caso de duas bandas, estes picos seriam colinas, enquanto que para três bandas eles tomariam a forma de esferas, e assim por diante. O conceito pode ser estendido para qualquer número de bandas. Uma vez localizados os picos, cada pixel pode ser associado na imagem ao pico mais próximo; assim, cada classe é rotulada como um agrupamento. É tarefa do analista identificar a classe de cobertura da terra de cada agrupamento, olhando a imagem de agrupamentos $\mathrm{e}$ comparando-a com as feições da paisagem.

O algoritmo CLUSTER oferece dois niveis de generalização. Com o nivel broad (grosseiro) de generalização, agrupamentos têm que ocorrer como picos distintos no histograma multi-dimensional. Porém, com o nivel fine (fino) de generalização, o CLUSTER reconhece também "ombros" da curva como picos de agrupamento. Os "ombros" acontecem quando dois agrupamentos adjacentes sobrepõem a uma extensão significativa. 
O algoritmo CLUSTER no IDRISI for Windows foi modificado para trabalhar com três bandas espectrais, formando uma imagem composta colorida. Este algoritmo é essencial para a geração de um histograma multi-dimensional do algoritmo de agrupamento. Considerando que é comum a experimentação de vários agrupamentos para uma única imagem multi-banda, a velocidade é grandemente aumentada pela não repetição deste passo na geração de histogramas. $\mathrm{Na}$ maioria dos casos, composições que empregam as bandas do vermelho, infravermelho próximo e infravermelho médio, conterão todas as informações essenciais da imagem.

\subsubsection{Algoritmo ISOCLUST}

O algoritmo ISOCLUST é um classificador nãosupervisionado, que auto-organiza, iterativamente, os pixels. É baseado em um conceito semelhante à famosa rotina de agrupamento denominada ISODATA de Ball \& Hall (1965), que utiliza procedimentos de K-médias. A lógica típica é como segue:

a) O usuário decide sobre o número de agrupamentos a ser criado. O analista é responsável por isto. A estratégia usual é solicitar um número maior de classes do que aquelas que foram detectadas pela observação da imagem. Uma aproximação mais eficiente para este problema é oferecida abaixo, baseada na implementação especifica em IDRISI for Windows;

b) Um conjunto de $\mathrm{N}$ agrupamentos é localizado, arbitrariamente, no espaço de bandas. Em alguns sistemas esta localização é feita ao acaso. $\mathrm{Na}$ maioria dos sistemas, são 
sistematicamente localizados dentro da região de reflectâncias de alta freqüência.;

c) Os pixels são, então, assinalados aos agrupamentos mais próximos;

d) Após todos os pixels terem sido assinalados, uma nova média é computada; e

e) Os passos c) e d) são repetidos iterativamente até que nenhuma mudança significativa seja produzida.

\subsubsection{Algoritmo MAXSET}

Este algoritmo cria classes intermediárias às classes básicas para onde os pixels com características intermediárias são colocados. As classes intermediárias representam pixels, cujas caracteristicas são indistingüiveis das classes básicas.

O algoritmo MAXSET é previamente descrito como um classificador tradicional que nomeia cada pixel à classe com a maior afinidade, pela teoria Dempster-Shafer. Esta teoria descreve todas as classes e suas combinações, hierarquicamente. Embora seja citado como um classificador supervisionado, pois requer amostras de treinamento com os dados do local, no final comporta-se como se fosse um classificador não-supervisionado.

O algoritmo MAXSET é muito semelhante em conceito ao Método do Paralelepípedo, à Minima Distância às Médias e ao classificador MAXVER, fazendo uma determinação rígida da classe a que pertence cada pixel, de acordo com sua própria lógica interna de operação. A lógica utilizada é derivada da teoria de Dempster-Shafer, uma variante especial da teoria de probabilidade Bayesina. O MAXSET 
avalia o grau de similaridade de todo pixel, hierarquicamente, que inclui cada uma das classes básicas mais todas as possiveis combinações de classes, que tem por função melhorar o desempenho da classificação não-supervisionada.

\subsection{Avaliação do Desempenho dos Algoritmos da Classificação Digital}

Uma das maneiras mais comuns de se avaliar a exatidão de uma classificação digital é pela aplicação de uma matriz de erros (matriz de confusão ou ainda tabela de contingência), segundo Lillesand e Kiefer (1994) e Congalton et al. (1983) (Tabela 2). Fazem parte desta técnica a normalização, o parâmetro Kappa e o exame simultâneo dos fatores (Congalton et al., 1983).

Neste processo, há a comparação entre a verdade terrestre e os resultados obtidos com a classificação digital. A matriz de erros consiste em igual número de colunas e linhas que representam as categorias. Nela, os dados de referência, representando a verdade terrestre, localizam-se nas colunas e, nas linhas, o resultado da classificação. Em uma matriz de erros, podemos analisar os erros de comissão (inclusão) e de omissão (exclusão) em uma classificação digital. Faz-se necessário calcular a exatidão geral somando-se o número de acertos na diagonal maior dividindo-se pelo número total de pixels da matriz. A exatidão do produtor é o resultado da divisão do número de pixel corretamente classificados pelo total de pixels corretos da categoria (número total da coluna). A exatidão do usuário é igual a divisão do número de pixel corretamente classificados pelo total de pixels classificados na categoria (número total da linha). Por meio desses 
valores é possivel realizar uma análise descritiva sobre a qualidade do mapeamento em cada uma das classes (Congalton, 1991). O número de amostras necessárias para avaliação da qualidade da classificação é determinado pela fórmula abaixo:

$$
\mathbf{N}=\mathbf{z}^{2} \mathbf{p q} / \mathbf{e}^{2}
$$

onde:

$z=$ número padrão;

$p=$ erro estimado razoável;

$q=(1-\mathrm{p}) \mathrm{e}$

$e=$ intervalo de confiança

Tabela 2. Matriz de confusão ou de erro.

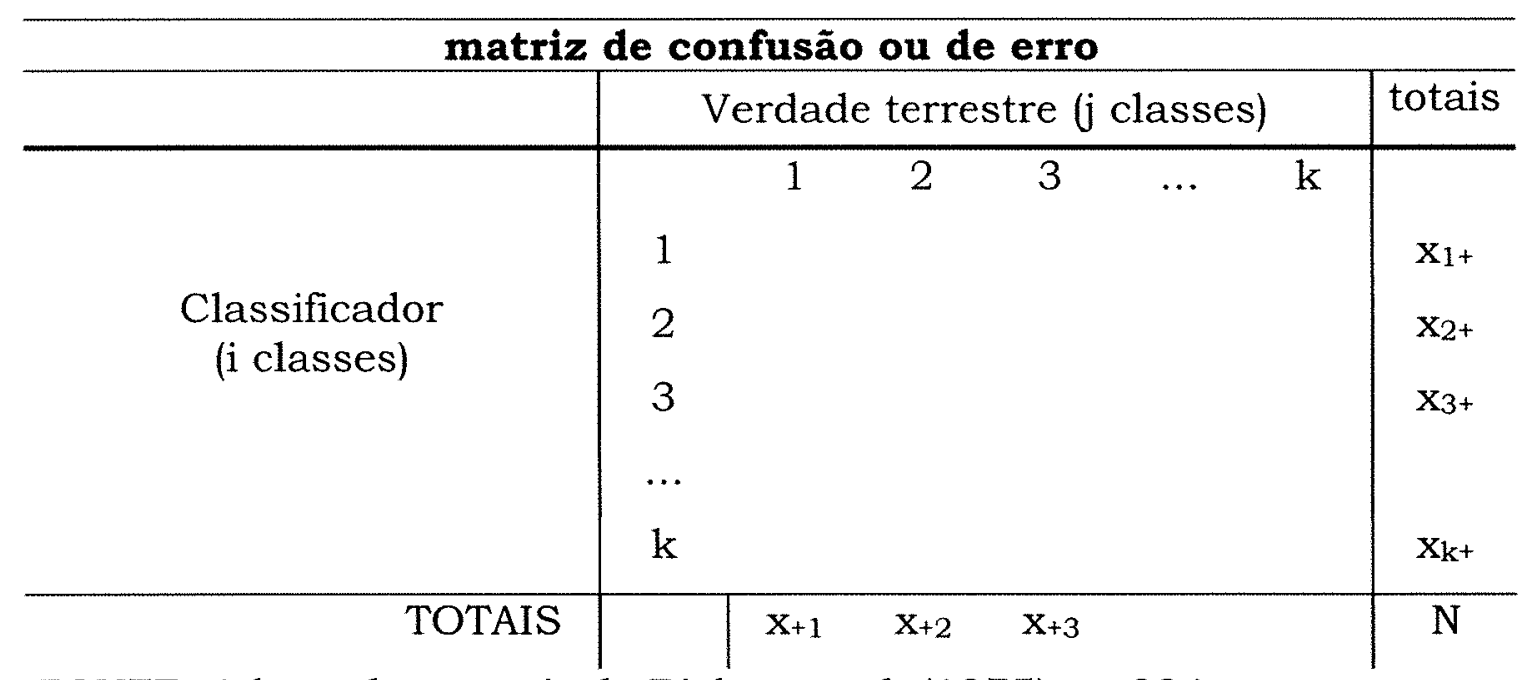

FONTE: Adaptada a partir de Bishop et al. (1975), p. 394.

A análise da matriz de erro destaca-se pela sua facilidade no cruzamento de mapas temáticos digitais na forma raster, ou matricial, possibilitando a verificação da concordância existente, pixel a pixel (Ponzoni e Almeida, 1996) e a avaliação da proporção de acerto, 
considerando que parte das classificações se devem ao acaso. O Índice Kappa considera toda a matriz de

erros, permitindo a comparação entre diversas classificações (Congalton, 1991).

$$
\hat{k}=\frac{N \sum_{i=1}^{r} x_{i i}-\sum_{i=1}^{r}\left(x_{i+} x_{+i}\right)}{N^{2}-\sum_{i=1}^{r}\left(x_{i+} x_{+i}\right)}
$$

onde:

$r=$ número de colunas na matriz de erros.

$\boldsymbol{x}_{\boldsymbol{i} i}=$ número de observações na linha $\boldsymbol{i}$ e na coluna $\boldsymbol{i}$ (diagonal maior da matriz).

$\boldsymbol{x}_{\boldsymbol{i +}}=$ total de observações na linha $\boldsymbol{i}$ (lateral direita da matriz)

$\boldsymbol{x}_{\boldsymbol{i} \boldsymbol{i}}=$ total de observações na coluna $\boldsymbol{i}$ (lateral inferior da matriz)

$\boldsymbol{N}=$ total de observações na matriz

A qualidade do Índice Kappa foi determinada por Landis e Koch (1977), distribuindo-se em faixas de valores (Tabela 3). 
Tabela 3. Qualidade do Índice Kappa, segundo sua faixa de coincidência (LANDIS E KOCH, 1977)

\begin{tabular}{cc}
\hline Kappa & Qualidade \\
\hline$<0,0$ & péssima \\
$0,0-0,2$ & ruim \\
$0,2-0,4$ & razoável \\
$0,4-0,6$ & boa \\
$0,6-0,8$ & muito boa \\
$0,8-1,0$ & excelente \\
\hline
\end{tabular}




\section{MATERIAL E MÉTODOS}

\subsection{Material}

\subsection{1 Área de Estudo}

A área de estudo corresponde à intersecção da Bacia do Rio Corumbataí com a imagem SPOT (Figura 1). Possui aproximadamente 166.012 ha e está compreendida entre as coordenadas $22^{\circ} 00^{\prime}$ a $22^{\circ} 45^{\prime}$ de latitude sul e $47^{\circ} 20^{\prime}$ a $47^{\circ} 55^{\prime}$ de longitude Oeste Grw., abrangendo a maior porção da Bacia do Rio Corumbatai, (aproximadamente 97,5\%), compreendendo parte dos municípios de Piracicaba, Rio Claro, Itirapina, Analândia, Corumbataí, Charqueada e Ipeúna. 


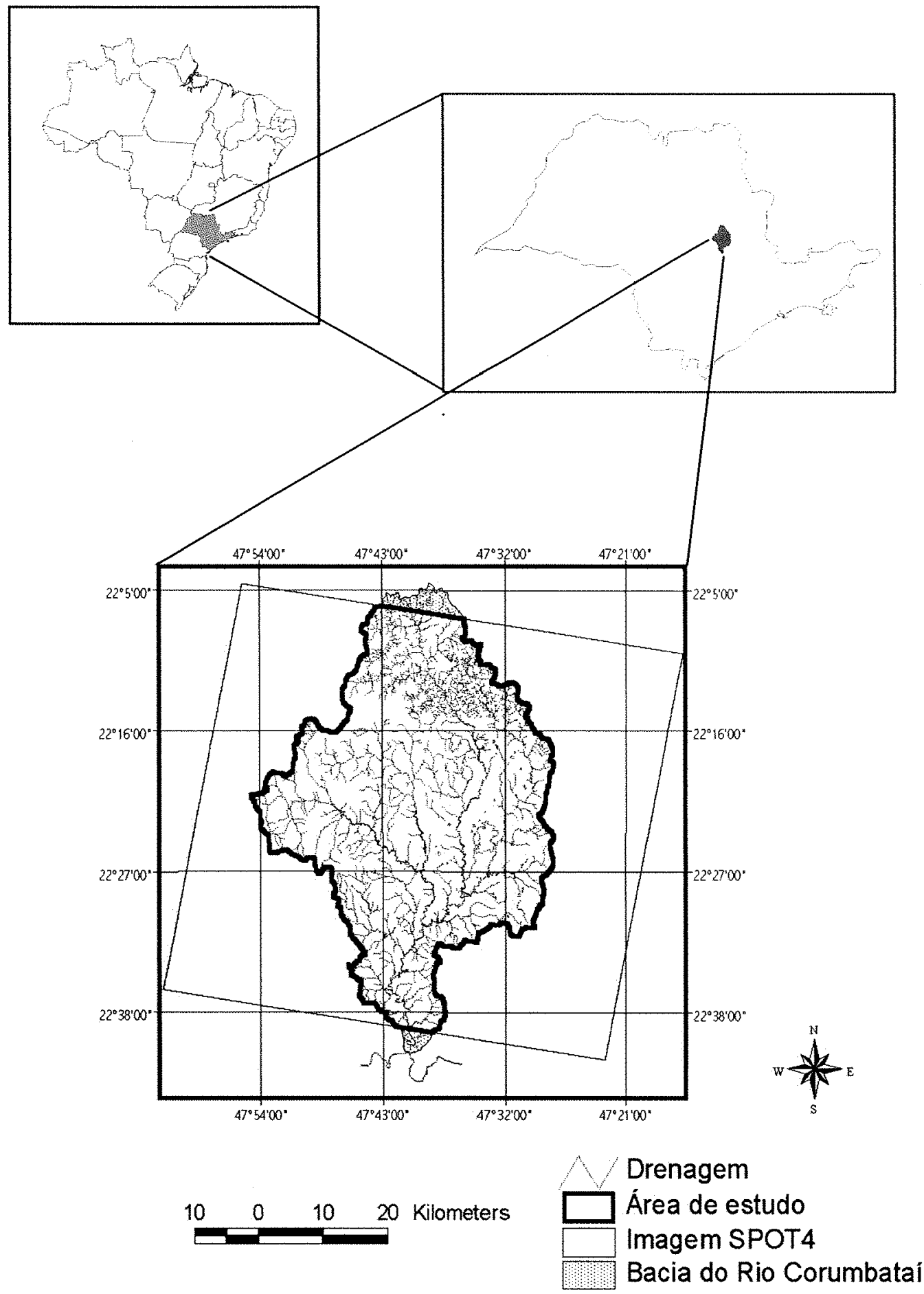

Figura 1 - Localização da Bacia do Rio Corumbataí e Área de estudo. 
O clima segundo Köppen, na Bacia é Cwa, mesotérmico de inverno seco, com temperaturas inferiores a $18,1^{\circ} \mathrm{C}$ no inverno e superiores a $23,7^{\circ} \mathrm{C}$ no verão (Brino, 1973). Nos meses de outono e inverno as amplitudes estão entre $15-30 \mathrm{~mm}$ mais seco, atingindo cerca de 1.000mm no Centro e Norte da Bacia (Zavatini e Cano, 1993).

A área em questão insere-se na formação geológica Corumbataí, contendo depósitos possivelmente marinhos de planícies de maré, incluindo argilitos, folhelhos e siltitos cinza amarelados ou avermelhados, com intercalações de bancos carboníticos, silexíticos e camadas de arenitos finos (IPT, 1981 a).

Geomorfologicamente, os relevos de degradação estão divididos em planaltos dissecados de relevo colinoso e relevo de morrotes (IPT, 1981 b).

De acordo com os levantamentos de solo realizados por Oliveira et al. (1979) e Oliveira e Prado (1989), mapeados em nível de semi-detalhe (escala 1:100.000) para as quadrículas geográficas de São Carlos, Araras, Campinas e Piracicaba, relatam a existência de 35 unidades de solos na Bacia, pertencentes a vários agrupamentos. Os grupos predominantes são os Solos Podzólicos Vermelhos Amarelos (43\%), seguidos pelos Latossolos Vermelhos Amarelos (21\%), Litólicos $(13,4 \%)$, Latossolos Roxos $(7 \%)$ e a existência de solos hidromórficos e aluviais, cinzas e negros, nas várzeas de depressōes interfluviais da bacia.

Com relação ao uso do solo, o IGC (1980) cita que existe predominância da atividade agrícola, com a presença de pastagem, silvicultura e vegetação nativa fragmentada.

Vettorazzi et al. (2000) trabalhando com imagem TM/Landsat-5 de 1993, citam que as áreas ocupadas com cana-deaçúcar totalizam $16,74 \%$ da área total da Bacia; já as áreas com 
pastagem perfazem um total de 40,75\%; e as áreas florestais plantadas e nativas totalizam $26,07 \%$ da Bacia.

\subsubsection{Equipamentos}

Para análise das imagens foi utilizado um Personal Computer de $200 \mathrm{Mhz}$, com $64 \mathrm{Mb}$ de memória RAM e um receptor Global, Positioning System (GPS) com 12 canais de navegação.

\subsubsection{Software}

Para o tratamento digital de imagens foram utilizados os "Softwares" de classificação digital de imagens "IDRISI for Windows" versão 2.00, utilizado para a classificação não-supervionada e ENVI, para a classificação supervisionada.

\subsubsection{Bases Cartográficas}

Para a elaboração de uma base cartográfica digital, foram utilizadas cartas topográficas da Fundação Instituto Brasileiro de Geografia e Estatística - IBGE, na escala de 1:50.000; e as cartas de Araras (SF-23-M-II-3) de 1969, Corumbataí (SF-23-Y-A-2) de 1971, Itirapina (SF-23-M-I-3) de 1969, Leme (SF-23-4A-II-1) de 1971, Limeira (SF-23-M-IV-1) de 1969, Piracicaba (SF-23-Y-A-IV-2) de 1969, Rio Claro (SF-13-M-I-4) de 1969, São Carlos (SF-23-M-II-1) de 1969 e São Pedro (SF-23-M-III-1) de 1969. A delimitação da Bacia do Rio Corumbataí foi 
digitalizada acompanhando o divisor de águas, sendo utilizado o software AUTOCAD 14.

\subsubsection{Imagem Digital}

Para este trabalho foi utilizada a imagem digital do satélite SPOT 4, disponibilizada pelo Serviço de Água e Esgoto de Piracicaba SEMAE, referente à passagem do dia 22 de setembro de 1999, das bandas X1, X2 e X3, correspondentes às bandas do verde, vermelho e infravermelho próximo, respectivamente.

\subsubsection{Fotografias aéreas}

Utilizou-se também de fotografias aéreas verticais, pancromáticas, na escala aproximada de 1:25.000, de 1995, fornecidas pelo SEMAE.

\subsection{Métodos}

A área da Bacia do Rio Corumbataí foi escolhida para a realização deste trabalho devido às características envolvidas no estudo, pela disponibilidade da imagem de satélite pelo SEMAE e para dar continuidade aos projetos já em desenvolvimento pelo Laboratório de Ciências Florestais, face sua proximidade para os trabalhos de campo.

Para a realização deste trabalho foi necessária a delimitação da área, o processamento digital, que consiste no pré- 
processamento, na classificação digital e na reclassificação, e a análise comparativa entre os diferentes algoritmos por meio de tabelas de confusão e do índice Kappa.

\subsubsection{Delimitação da área de estudo e Definição das classes de cobertura}

Os limites da área de estudo correspondem a parcela da imagem abrangida pela Bacia do Rio Corumbaí, definida pela demarcação dos divisores de água extraídos de cartas do IBGE, na escala 1:50.000, havendo uma visita em campo para observar a paisagem e seus elementos como uso e ocupação da terra e aspectos fisiográficos.

Os dados de cobertura foram marcados em uma imagem impressa com a anotação das possiveis classes a serem determinadas. Posteriormente, os padrões das classes foram identificados na imagem SPOT 4 georreferenciada, contando com o auxilio de fotografias aéreas, bibliografia e informações de campo, definindo as categorias de cobertura da terra abaixo:
1) Solo nu
2) Área urbana
3) Cana-de-açúcar
4) Pastagem
5) Reflorestamento
6) Vegetação nativa 


\subsubsection{Pré-Processamento da Imagem Digital}

Para a utilização da imagem digital foram realizadas correções, com o objetivo de reduzir as distorções existentes e prepará-la para a aplicação dos algoritmos de classificação. Assim, foram realizadas as seguintes correções para o pré-processamento:

\section{Correção radiométrica}

A imagem do SPOT 4 utilizada já havia recebido a correção radiométrica, sendo necessário apenas executar as correções atmosférica e geométrica.

\section{Correção atmosférica}

A correção atmosférica foi aplicada nas três bandas do SPOT 4 utilizando-se o método da reflectância zero, com o auxílio do software IDRISI 2.0 .

\section{Correção geométrica}

Para este trabalho foi utilizado o software ENVI, e cartas topográficas do IBGE 1:50.000 (1969 e 1971), com 140 pontos de controle, com o uso da equação polinomial e atribuição do nível de cinza pelo vizinho mais próximo. A Figura 2 mostra uma composição colorida das bandas 1,2 e 3 do SPOT 4 georreferenciada. 


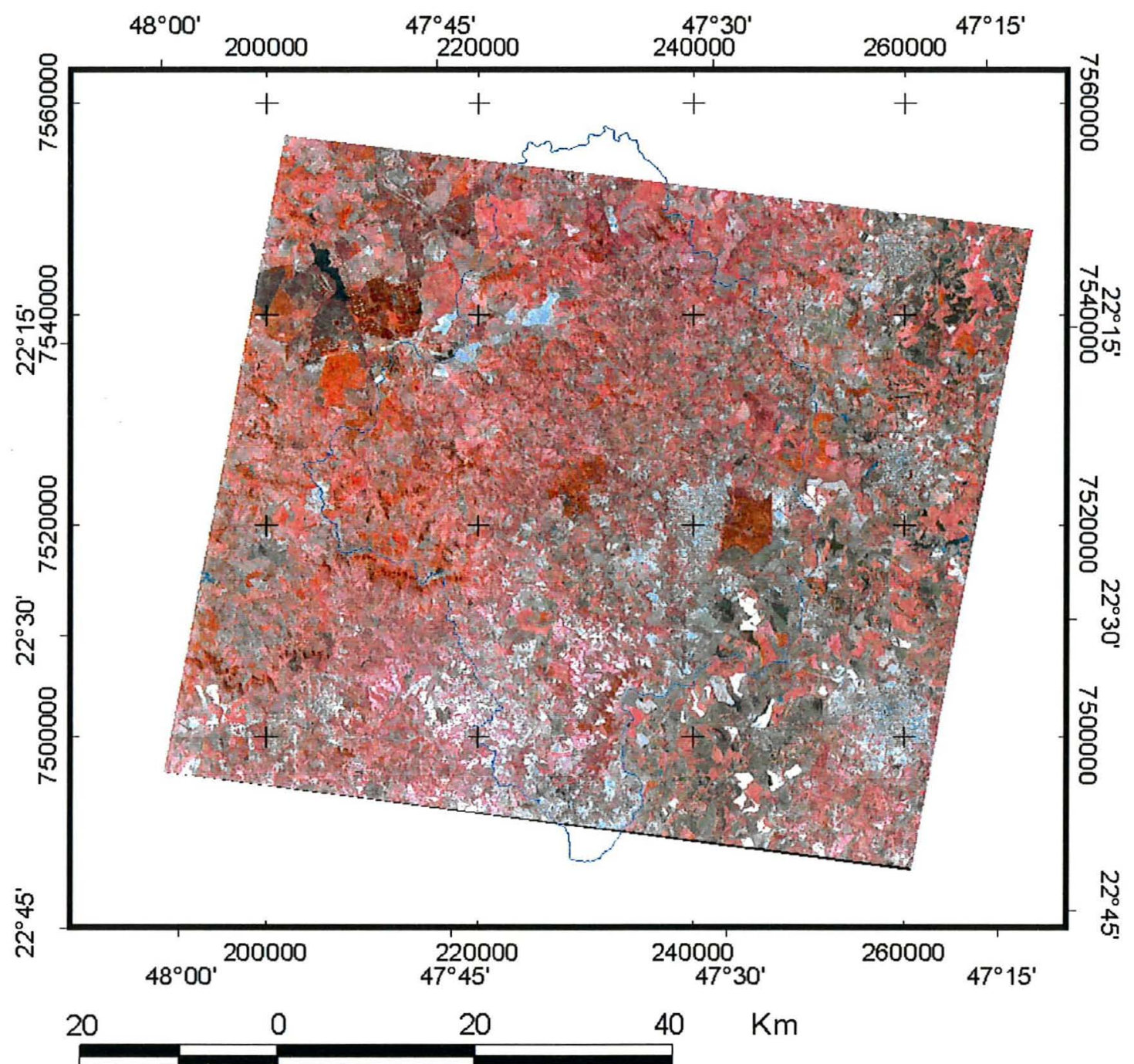

Limite da bacia $\square$

Figura 2 - Composição colorida da imagem corrigida geometricamente. 


\subsubsection{Classificação da Imagem Digital}

No processo de classificação digital de imagens, foram empregados, numa avaliação comparativa, os algoritmos de classificação não-supervisionada, presentes no software para geoprocessamento IDRISI for Windows versão 2.00 (Eastman, 1997). Foram avaliados os seguintes algoritmos: CLUSTER, ISOCLUST e MAXSET.

Para efeito de comparação foi também empregado o algoritmo da Máxima Verossimilhança, presente no software para geoprocessamento ENVI.

\subsubsection{Classificação supervisionada}

\section{- Algoritmo da Máxima Verossimilhança (MAXVER)}

Este algoritmo requereu a delimitação, em tela, de amostras das classes de cobertura na imagem, sendo ajustada mais de uma vez, de forma que os padrōes das classes presentes fossem reconhecidos. Desta forma foi utilizada uma composição colorida utilizando-se das três bandas disponiveis. Para cada banda foi associada uma cor no sistema RGB ("Red, Green e Blue"), utilizando-se para esta tarefa o software ENVI. Nem sempre as associações utilizadas permitiam a identificação clara dos alvos, sendo necessário alterar a atribuição de cores às bandas, o que permitiu distinguir alvos pouco perceptiveis em algumas associações de cores.

Após o reconhecimento de campo, correção atmosférica e registro, passou-se à fase de coleta de amostras de treinamento para o algoritmo MAXVER. Obteve-se 28 subclasses, que foram amostradas 
para esta classificação, atingindo $2 \%$ do total de pixels da imagem. Assim, a suficiência amostral foi atingida, considerando que o tamanho da amostra deve estar entre $1,5 \%$ a $3 \%$ dos pixels da imagem e o total de pixels em cada categoria (Eastman, 1997).

Para a definição de amostras de treinamento procurou-se utilizar o histograma de cada classe para se conseguir uma distribuição normal dos pixels de cada classe uma vez que era visualmente dificil a delimitação homogênea. Este procedimento foi adotado em todas as áreas, mesmo em regiões onde o relevo era relativamente plano e tendo a cana-de-açúcar como cultura predominante.

\subsubsection{Classificação não-supervisionada}

- Cluster

Foi criada uma composição colorida das três bandas do SPOT 4 necessárias para o funcionamento deste algoritmo no software IDRISI 2.0, sendo solicitadas 35 categorias utilizando-se a opção Broad.

\section{- Isoclust}

Foi estabelecido um número mínimo de 3 iterações, pois o tempo de processamento aumenta com o número de iterações sem que haja melhoria na discriminação de classes. Nesta versão do software Idrisi o número de classes máximo não é determinado automaticamente, devendo ser estabelecido pelo usuário. Desta forma foi necessário inserir valores crescentes de número de classes até se obter o número limite. 


\section{- MAXSET}

Para este algoritmo foram utilizadas as mesmas amostras de treinamento da classificação supervisionada com as quais foram criadas imagens para cada classe identificada. Em seguida foi inserida a probabilidade de cada classe utilizada

\subsubsection{Reclassificaçāo}

A reclassificação tem por objetivo reunir subclasses em suas classes correspondentes, facilitando a compreensão da classificação. A técnica consiste em colocar o mesmo índice para subclasses afins, o que é realizado pela função RECLASS no IDRISI.

A reclassificação foi feita com o auxilio da composição colorida e das fotografias aéreas para a determinação da categoria a qual pertence a subcategoria observada, realizada com a função RECLASS no IDRISI 2.0, sendo a categoria determinada para a classe que mais se identificasse com as categorias estabelecidas.

Para a construção dessa matriz foi necessário amostrar os pontos de controle. O resultado obtido foi representativo de uma parcela da área. Por meio de uma regra de três obteve-se o número de pontos total.

O módulo do IDRISI empregado foi o ERRMAT, que tabula erros de omissão e comissão, erros totais e marginais e intervalos de confiança selecionados. Também é apresentado o Índice de Kappa de Concordância, global e por categoria mapeada. 


\subsubsection{Avaliação do Mapeamento}

Para avaliar a exatidão das classificações foi utilizada a matriz de confusão, tendo sido necessária uma amostragem representativa de pontos para aplicação do índice Kappa.

A amostragem foi realizada com distribuição de pontos estratificada ao acaso, utilizando as fórmulas de Eastman (1997), totalizando 137 pontos. A maioria dos pontos puderam ser confirmados pela observação na própria imagem ou com o auxílio de fotografias aéreas. Nas áreas onde não foi possivel essa confirmação, a observação em campo foi necessária, utilizando-se um receptor GPS para localização dos pontos.

De posse da determinação da categoria nesses pontos foi gerada uma imagem da verdade terrestre, contendo a informação correta de cada pixel em suas devidas posições. A imagem resultante foi confrontada com os resultados das classificações utilizando-se a função ERRMAT do software IDRISI 2.0, que gerou uma tabela de confusão com os valores de Kappa. 


\title{
4 RESULTADOS E DISCUSSÃO
}

\begin{abstract}
A delimitação de áreas de treinamento necessária à classificação supervisionada mostrou-se muito demorada devido às caracteristicas da imagem da área de estudo, onde haviam variações sutis entre algumas classes como cana-de-açúcar e pastagem, sendo necessário a consulta de outras fontes de informação para a redução de dúvidas, o que concorda com Fonseca (1995) porém, o resultado pode variar muito quando se está próximo do limite de percepção visual, interferindo no resultado final da classificação, (Crosta, 1992). Várias tentativas de delimitação foram executadas devido a essas características. Histogramas das classes foram utilizados para melhorar a caracterização de uma categoria. A coincidência dos histogramas de classes como cana-de-açúcar e pasto impossibilitou em alguns casos, a sua diferenciação. Pode-se evitar a confusão na classificação de culturas conhecendo-se a época de plantio, no caso da utilização de imagens unitemporais (Chen, 1988).
\end{abstract}

De posse da matriz de confusão, os valores das tabelas são convertidos em porcentagem, contendo também as tabelas de exatidão geral para cada algoritmo, bem como os dados da exatidão do produtor e exatidão do usuário para cada classe, também em porcentagem (Congalton, 1991).

Como o número de amostras para a comparação foi sempre o mesmo, não foi necessário realizar a normalização para as tabelas dos 
diferentes classificadores. Para avaliar a qualidade dos valores foram levados em consideração o Kappa geral e exatidão geral.

A seguir, com auxílio do Índice Kappa, das matrizes de confusão e exatidão é realizada uma análise das classes de cobertura da terra classificadas pelos algoritmos de classificação digital e a influência da filtragem na exatidão da classificação.

\section{MAXVER não filtrado}

Para a o algoritmo MAXVER não filtrado a E.G foi de $52,21 \%$, de acordo com a Tabela 4, com Kappa geral de 0,5849 (Tabela 13), considerada boa de acordo com a Tabela 3. De acordo com a Tabela 4, para a classe Solo nu houve atribuição de $71,79 \%$ dos pixels, havendo erro de omissão com atribuição à classe Vegetação nativa, que não tem semelhança espectral. Foram atribuidos $80 \%$ dos pixels corretamente à classe, ocorrendo erro de comissão com inclusão de pixels das classes Cana-de-açúcar, principalmente, e Área urbana.

A Área urbana não foi classificada com a utilização do sensor passivo.

Para a classe Cana-de-açúcar, foram atribuídos $20 \%$ dos pixels, havendo erro de omissão, com atribuição de pixels às classes Vegetação nativa, Cana-de-açúcar e Solo nu, indicando que a classe não está bem definida espectralmente, com a utilização das bandas utilizadas. Foram atribuídos corretamente $20 \%$ dos pixels à classe, com inclusão, por erro de comissão, dos pixels da classe Pastagem, o que pode ser explicado devido a semelhança espectral entre as espécies de graminea.

Para a classe Pastagem foram atribuídos $50 \%$ dos pixels, havendo erro de omissão, principalmente para a classe Vegetação 
nativa. Foram atribuidos $62 \%$ dos pixels corretamente à classe, havendo erro de comissão, principalmente com a inclusão de pixels das classes Vegetaçāo nativa, Cana-de-açúcar, Área urbana e Solo nu.

Foram atribuídos $100 \%$ dos pixels à classe Reflorestamento, não ocorrendo erros de omissão ou comissão.

Foram atribuídos $36,84 \%$ dos pixels à classe Vegetação nativa, havendo erro de omissão, com atribuição da classe Pastagem, principalmente. Foram corretamente atribuidos $18,42 \%$ dos pixels à classe Vegetação nativa, havendo muitos erros por comissão, com inclusão, principalmente, da classe Pastagem e também Solo nu e Cana-de-açúcar (Tabela 4).

Tabela 4. Matriz de confusão e Exatidão de acerto do algoritmo MAXVER representados em porcentagem.

\begin{tabular}{crrrrrrr}
\hline & S.N. & A.U. & C.A. & P. & R. & V.N. & Total \\
\hline S.N. & 28 & 1 & 2 & 4 & 0 & 0 & 35 \\
C.A. & 1 & 0 & 2 & 6 & 0 & 1 & 10 \\
P. & 3 & 2 & 3 & 31 & 0 & 11 & 50 \\
R. & 0 & 0 & 0 & 0 & 3 & 0 & 3 \\
V.N. & 7 & 0 & 3 & 21 & 0 & 7 & 38 \\
Total & 39 & 3 & 10 & 62 & 3 & 19 & 136 \\
E.G. & 52,21 & & & & & & \\
E.P. & 71,79 & 0,00 & 20,00 & 50,00 & 100,00 & 36,84 & \\
E.U. & 80,00 & 0,00 & 20,00 & 62,00 & 100,00 & 18,42 \\
S N. = Solo nu; A.U.= Área urbana; C.A. = Cana-de-açúcar; P = \\
Pastagem; R = Reflorestamento; V.N = Vegetação nativa; E.G. = Exatidão \\
Geral; E.P. = Exatidão do produtor e E.U. = Exatidão do usuário.
\end{tabular}

\section{MAXVER filtrado}

Para o algoritmo MAXVER filtrado a E.G., de acordo com a Tabela 5, foi de 74,26\%, com Kappa geral de 0,601 (Tabela 12), 
considerada muito boa de acordo com a Tabela 5. Para a classe Solo nu houve atribuição de $61,54 \%$ dos pixels ocorrendo erro de omissão, onde os pixels foram atribuídos à classe Pastagem, devido a semelhanças espectrais entre elas. Destes pixels atribuidos, $82,76 \%$ realmente pertenciam à classe, ocorrendo erro de comissão, e o restante pertencia, principalmente, à classe Pastagem.

Não houve atribuição de pixels para a classe Área urbana, visto que nesses locais, devido às características desse tipo de cobertura, era representado por telhados, ruas, áreas verdes, entre outras, formando um mosaico e não uma categoria homogênea. Concordando com Kuplich (1994), para a delimitação destas áreas, poderiam ser utilizados sensores ativos (Tabela 5 ).

Conforme a Tabela 5, foram atribuídos $20 \%$ dos pixels à classe Cana-de-açúcar, havendo erro de omissão, com atribuição dos pixels à classe Pastagem, devido a suas semelhanças espectrais. Foram atribuídos corretamente $40 \%$ dos pixels à classe; ocorrendo erro de comissão, havendo inclusão de pixels das classes Pastagem e Vegetação nativa, que não tem fisionomia semelhante com a classe atribuída.

Foram atribuidos à classe Pastagem 91,94\% dos pixels, havendo erro de omissão, sendo estes pixels atribuidos à classe Solo nu. Destes pixels atribuidos, $69,51 \%$ pertenciam à classe e o restante às classes Solo nu, principalmente, Cana-de-açúcar e Área urbana.

Para a classe Reflorestamento houve atribuição de 100\% dos pixels, não havendo mudanças devido a filtragem, não havendo erros de omissão ou comissão.

A classe Vegetação nativa teve $78,95 \%$ dos pixels atribuidos, sendo que a parcela omitida pertencia principalmente à 
classe Pastagem, que não guarda semelhanças fisionômicas com essa classe. Não houve erro de comissão.

O resultado da classificação pode ser visualizado na Figura 3 , onde nota-se grande extensão de pastagens, inclusive em áreas onde a Cana-de-açúcar estava presente.

Tabela 5. Matriz de confusão e Exatidão de acerto do algoritmo MAXVER com filtro de mediana $3 \times 3$ representados em porcentagem.

\begin{tabular}{crrrrrrr}
\hline & S.N. & A.U. & C.A. & P. & R. & V.N. & Total \\
\hline S.N. & 24 & 1 & 1 & 3 & 0 & 0 & 29 \\
A.U. & 2 & 0 & 0 & 0 & 0 & 0 & 2 \\
C.A. & 0 & 0 & 2 & 2 & 0 & 1 & 5 \\
P. & 13 & 2 & 7 & 57 & 0 & 3 & 82 \\
R. & 0 & 0 & 0 & 0 & 3 & 0 & 3 \\
V.N. & 0 & 0 & 0 & 0 & 0 & 15 & 15 \\
Total & 39 & 3 & 10 & 62 & 3 & 19 & 136 \\
E.G. & 74,26 & & & & & & \\
E.P. & 61,54 & 0,00 & 20,00 & 91,94 & 100,00 & 78,95 & \\
E.U. & 82,76 & 0,00 & 40,00 & 69,51 & 100,00 & 100,00 & \\
\hline
\end{tabular}

S N. = Solo nu; A.U.= Área urbana; C.A. = Cana-de-açúcar; $\mathrm{P}=$ Pastagem; $\mathrm{R}=$ Reflorestamento; V.N = Vegetação nativa; E.G. = Exatidão Geral; E.P. = Exatidão do produtor e E.U. = Exatidão do usuário. 


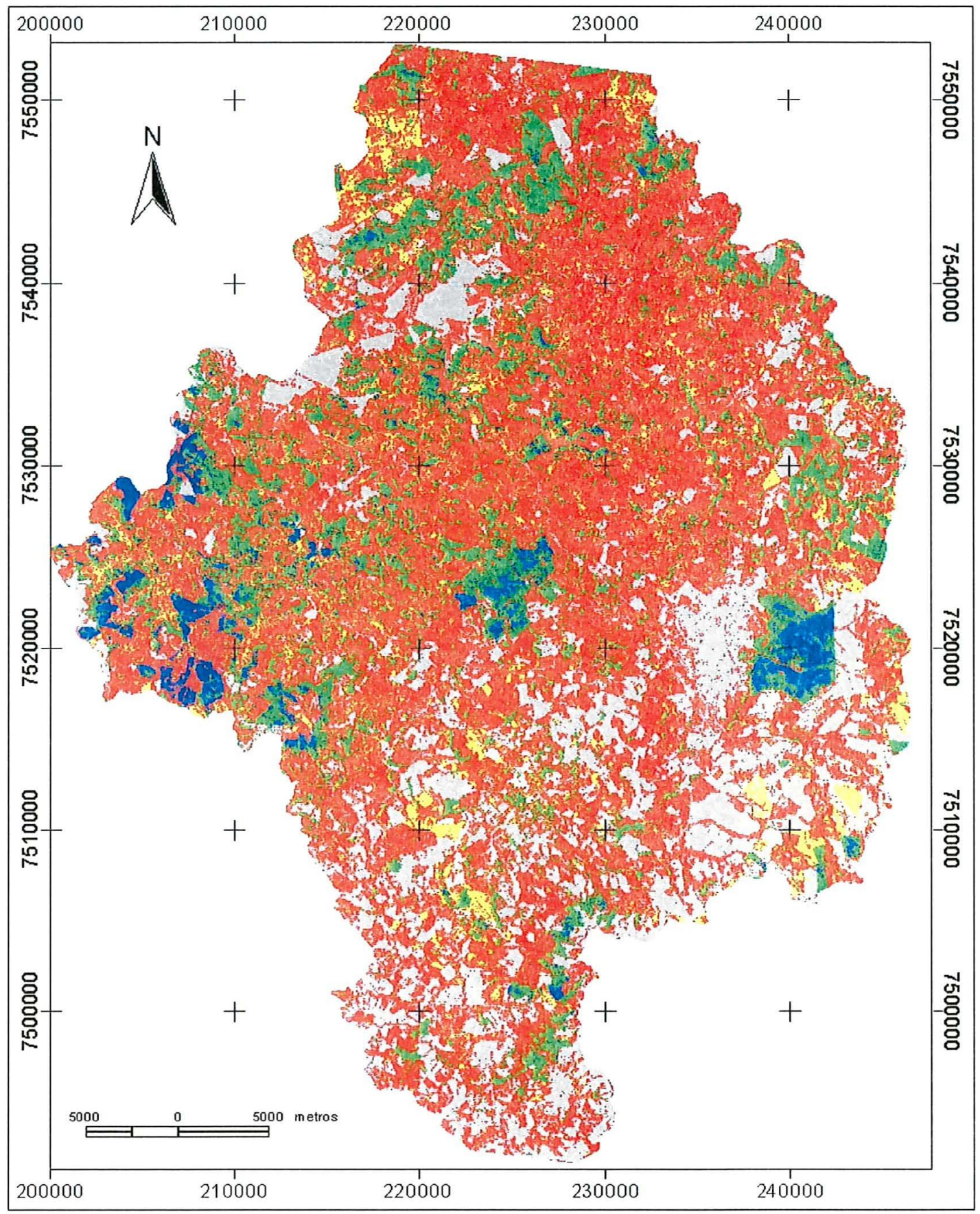

$\square$ Solo nu $\square$ Cana-de-açúcar $\square$ Pastagem $\square$ Reflorestamento $\square$ Vegetação nativa

Figura 3 - Reclassificação das 28 subclasses após utilização do algoritmo MAXVER 


\section{ISOCLUST não filtrado}

Para o ISOCLUST não filtrado a E.G., de acordo com a Tabela 6, foi de 65,44\% com um Kappa geral de 0,5066, considerada boa de acordo com a Tabela 3 . Foram atribuidos 58,97\% dos pixels à classe Solo nu, ocorrendo erro de omissão, com atribuição às classes Pastagem, Vegetação nativa e Cana-de-açúcar. Nota-se a discriminação pouco evidente entre a Pastagem e o Solo nu. Foram atribuídos corretamente $92 \%$ dos pixels à classe Pastagem, ocorrendo erro de comissão, com inclusão de pixels da classe Cana-de-açúcar, devido, provavelmente, à existência de áreas com Cana-de-açúcar recém cortada que expõe o solo (Tabela 6).

Pelos mesmos motivos apresentados no MAXVER FILTRADO, não foram atribuídos pixels à classe Área urbana.

Para a classe Cana-de-açúcar foram atribuidos apenas $20 \%$ dos pixels, havendo erro de omissão, com atribuição de pixels às classes Pastagem, Solo nu e Vegetação nativa. Apenas $15,38 \%$ dos pixels pertenciam realmente à classe, com inclusão, por erro de comissão, de pixels das classes Pastagem, Solo nu e Área urbana. Desta forma, observa-se que existem diversas características comuns a essas três classes, que as tornam dificeis de caracterizar.

Para a classe Pastagem foram atribuídos $70,97 \%$ dos pixels, ocorrendo erro de omissão, com atribuição às classes Vegetação nativa e Cana-de-açúcar. As classes não tem uma ligação direta quanto à fisionomia. Foram corretamente atribuídos $72,13 \%$ dos pixels à classe, havendo erro de comissão, com inclusão de pixels pertencentes às classes Solo nu, Cana-de-açúcar e Área urbana.

Todos os pixels da classe Reflorestamento foram classificados corretamente. 
A classe Vegetação nativa teve $89,47 \%$ dos pixels atribuídos à classe, havendo erro de omissão, com atribuição às classes Cana-de-açúcar e Pastagem. Apresentou porém 50\% de erro de comissão, com inclusão das classes Pastagem, principalmente, e Solo nu.

Tabela 6. Matriz de confusão e Exatidão de acerto do algoritmo ISOCLUST representados em porcentagem:

\begin{tabular}{crrrrrrr}
\hline & S.N. & A.U. & C.A. & P. & R. & V.N. & Total \\
\hline S.N. & 23 & 0 & 2 & 0 & 0 & 0 & 25 \\
C.A. & 3 & 1 & 2 & 6 & 0 & 1 & 13 \\
P. & 9 & 2 & 5 & 44 & 0 & 1 & 61 \\
R. & 0 & 0 & 0 & 0 & 3 & 0 & 3 \\
V.N. & 4 & 0 & 1 & 12 & 0 & 17 & 34 \\
Total & 39 & 3 & 10 & 62 & 3 & 19 & 136 \\
E.G. & 65,44 & & & & & & \\
E.P. & 58,97 & 0,00 & 20,00 & 70,97 & 100,00 & 89,47 & \\
E.U. & 92,00 & 0,00 & 15,38 & 72,13 & 100,00 & 50,00 \\
\hline S N. = Solo nu; A.U.= Área urbana; C.A. = Cana-de-açúcar; P = \\
Pastagem; R = Reflorestamento; V.N = Vegetação nativa; E.G. = Exatidão \\
Geral; E.P. = Exatidão do produtor e E.U. = Exatidão do usuário.
\end{tabular}

ISOCLUST com filtragem

O algoritmo ISOCLUST com filtragem apresentou uma E.G. de 63,97\%, com um Kappa geral de 0,4973, considerada boa de acordo com a Tabela 3. Foram atribuídos $56,41 \%$ dos pixels à classe Solo nu, ocorrendo erro de omissão, com atribuição dos pixels às classes Canade-açúcar, Solo nu e Vegetação nativa. Foram atribuídos $88 \%$ dos pixels à classe, por erro de comissão houve inclusão de pixels das classes Cana-de-açúcar e Área urbana. 
Para a classe Área urbana não houve atribuição de pixels (Tabela 7).

Foram atribuídos $40 \%$ dos pixels à classe Cana-de-açúcar, ocorrendo erro de omissão, com atribuição dos pixels às classes Pastagem, Solo nu e Vegetação nativa. Foram atribuídos corretamente $22,22 \%$ dos pixels para a classe, ocorrendo erro de comissão, com inclusão de pixels das classes Pastagem, Solo nu e Vegetação nativa.

Para a classe Pastagem foram atribuídos $66,13 \%$ dos pixels, ocorrendo erro de omissão, com atribuição dos pixels às classes Solo nu, Cana-de-açúcar e Vegetação nativa. Foram atribuídos corretamente $74,55 \%$ dos pixels à classe, havendo erro de comissão, com inclusão dos pixels das classes Solo nu, Cana-de-açúcar, Área urbana e Vegetação nativa.

Foram atribuídos $100 \%$ dos pixels à classe Reflorestamento. Não houve erros por omissão ou comissão.

Para a classe Vegetação nativa foram atribuídos $89,47 \%$ dos pixels, ocorrendo erro de omissão, com atribuição dos pixels às classes Cana-de-açúcar e Pastagem. Foram atribuídos $48,57 \%$ dos pixels corretamente, ocorrendo erro de comissão com inclusão dos pixels das classes Pastagem, Solo nu e Cana-de-açúcar.

Como pode ser observado na Figura 4, existe um número grande de fragmentos da classe Vegetação nativa, que não é bem visualizado na composição colorida do SPOT 4. 
Tabela 7. Matriz de confusão e Exatidão de acerto do algoritmo ISOCLUST com filtro de mediana $3 \times 3$ representados em porcentagem.

\begin{tabular}{crrrrrrr}
\hline & S.N. & A.U. & C.A. & P. & R. & V.N. & Total \\
\hline S.N. & 22 & 1 & 2 & 0 & 0 & 0 & 25 \\
C.A. & 6 & 0 & 4 & 7 & 0 & 1 & 18 \\
P. & 8 & 2 & 3 & 41 & 0 & 1 & 55 \\
R. & 0 & 0 & 0 & 0 & 3 & 0 & 3 \\
V.N. & 3 & 0 & 1 & 14 & 0 & 17 & 35 \\
Total & 39 & 3 & 10 & 62 & 3 & 19 & 136 \\
E.G. & 63,97 & & & & & & \\
E.P. & 56,41 & 0,00 & 40,00 & 66,13 & 100,00 & 89,47 & \\
E.U. & 88,00 & 0,00 & 22,22 & 74,55 & 100,00 & 48,57 & \\
\hline
\end{tabular}

S N. = Solo nu; A.U.= Área urbana; C.A. = Cana-de-açúcar; $\mathrm{P}=$

Pastagem; $\mathrm{R}=$ Reflorestamento; V.N = Vegetação nativa; E.G. = Exatidão

Geral; E.P. = Exatidão do produtor e E.U. = Exatidão do usuário. 


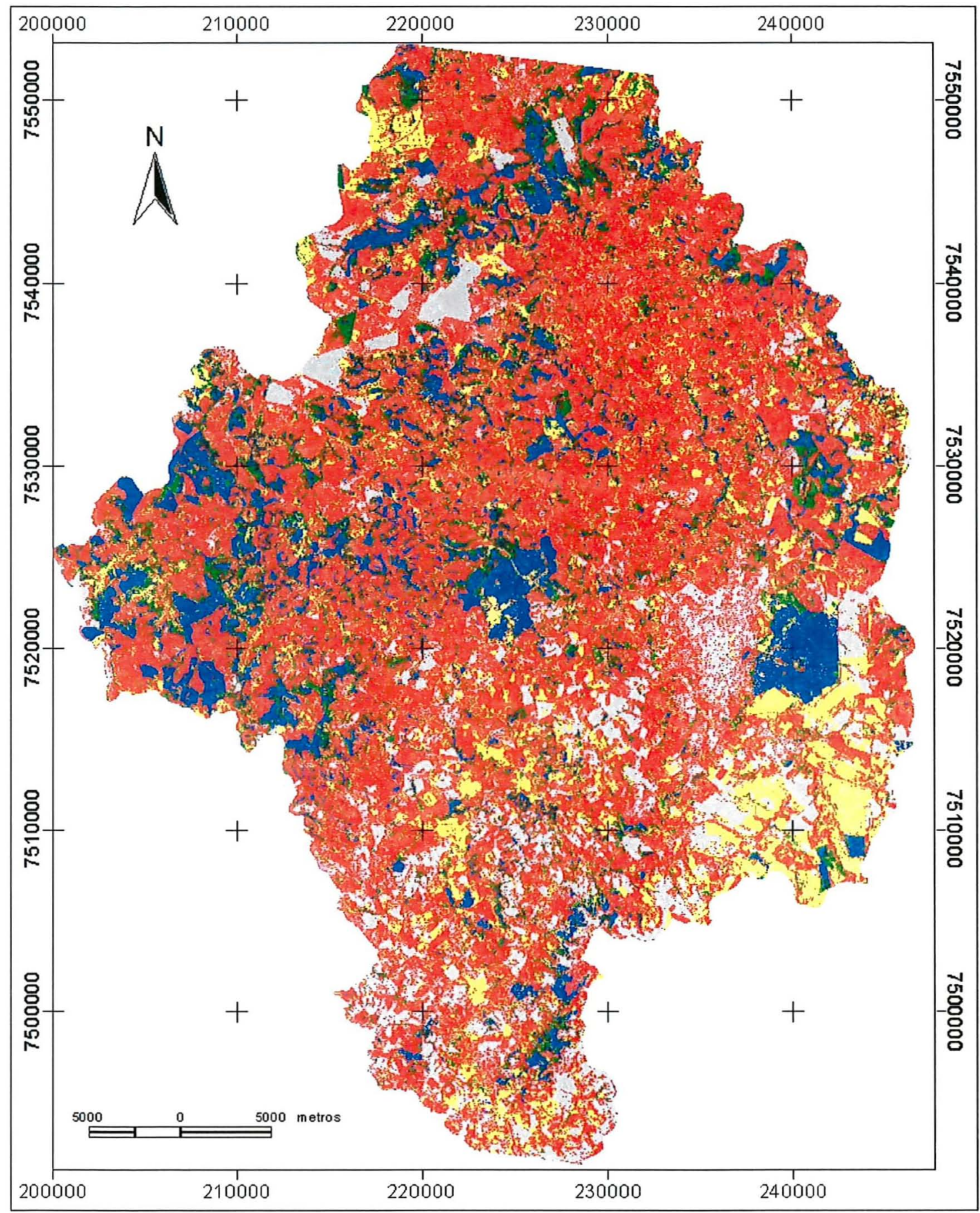

Solo nu $\square$ Cana-de-açúcar $\square$ Pastagem $\square$ Reflorestamento $\square$ Vegetaçăo nativa

Figura 4 - Reclassificação das 34 subclasses obtidas pelo algoritmo ISOCLUST 


\section{CLUSTER nāo filtrado}

Para o algoritmo CLUSTER não filtrado a E.G. foi de 56,62 conforme a Tabela 8, com o Kappa geral de 0,3529, sendo considerada razoável de acordo com a Tabela 3 . Como pode ser observado na Tabela 8, foram atribuídos $33,33 \%$ dos pixels à classe Solo nu, ocorrendo erro de omissão, com atribuição da maior dos pixels à classe Pastagem, Cana-de-açúcar e Vegetação nativa. Foram atribuídos corretamente $81,25 \%$ dos pixels à classe, ocorrendo erro de comissão, com inclusão dos pixels das classes Área urbana, Cana-de-açúcar e Pastagem.

Não foram atribuidos pixels à classe Área urbana.

Para a classe Cana-de-açúcar foram atribuídos 10\% dos pixels, ocorrendo erro de omissão, com atribuição dos pixels às classes Pastagem (a maior parcela) e Solo nu. Foram atribuídos corretamente $7,14 \%$ dos pontos à classe, ocorrendo erro de comissão, com inclusão das classes Solo nu, Pastagem e Vegetação nativa, ou seja, este classificador não é capaz de separar as categorias Cana-de-açúcar e Pastagem, não sendo um algoritmo indicado para diferenciar estas classes.

Foram atribuídos $85,48 \%$ dos pixels à classe Pastagem, ocorrendo erro de omissão, com atribuição dos pixels às classes Canade-açúcar e Vegetação nativa. Destes pixels, 64,63\% foram atribuídos corretamente à classe, sendo incluídos por erro de comissão, pixels pertencentes às classes Solo nu, Cana-de-açúcar, Área urbana e Vegetação nativa.

Para a classe Reflorestamento foram atribuídos $100 \%$ dos pixels., porém ocorreu a inclusão, por erro de comissão, dos pixels da classe Vegetação nativa, sendo pertencentes à classe apenas 23,08\%. 
Foram atribuídos $36,84 \%$ dos pixels à classe Vegetação nativa, ocorrendo erro de omissão, sendo atribuídos pixels das classes Reflorestamento, Pastagem e Cana-de-açúcar. Foram atribuídos corretamente $63,64 \%$ dos pixels à classe, ocorrendo erro de comissão, com inclusão dos pixels das classes Pastagem e Solo nu.

Tabela 8. Matriz de confusão e Exatidão de acerto do algoritmo CLUSTER representados em porcentagem.

\begin{tabular}{crrrrrrr} 
& S.N. & A.U. & C.A. & P. & R. & V.N. & Total \\
\hline S.N. & 13 & 1 & 1 & 1 & 0 & 0 & 16 \\
C.A. & 7 & 0 & 1 & 5 & 0 & 1 & 14 \\
P. & 18 & 2 & 8 & 53 & 0 & 1 & 82 \\
R. & 0 & 0 & 0 & 0 & 3 & 10 & 13 \\
V.N. & 1 & 0 & 0 & 3 & 0 & 7 & 11 \\
Total & 39 & 3 & 10 & 62 & 3 & 19 & 136 \\
E.G. & 56,62 & & & & & & \\
E.P. & 33,33 & 0,00 & 10,00 & 85,48 & 100,00 & 36,84 & \\
E.U. & 81,25 & 0,00 & 7,14 & 64,63 & 23,08 & 63,64 & \\
\hline
\end{tabular}

S N. = Solo nu; A.U.= Área urbana; C.A. = Cana-de-açúcar; P = Pastagem; $\mathrm{R}=$ Reflorestamento; V.N = Vegetação nativa; E.G. = Exatidão Geral; E.P. = Exatidão do produtor e E.U. = Exatidão do usuário.

\section{CLUSTER filtrado}

Para o algoritmo CLUSTER filtrado a E.G., de acordo com a Tabela 9 foi de 55,88\%, com Kappa geral de 0,3641, considerada razoável de acordo com a Tabela 3 . Na Tabela 9 pode-se observar que $38,46 \%$ dos pixels foram atribuídos para a classe Solo $\mathbf{n u}$, havendo erro de omissão, com atribuição dos pixels às classes Pastagem, Cana-deaçúcar e Vegetação nativa. Foram atribuídos corretamente $88,24 \%$ dos pixels à classe, ocorrendo erro de comissão, com inclusão de pixels das classes Cana-de-açúcar e Área urbana.

Não foram atribuídos pixels para a classe Área urbana. 
Para a classe Cana-de-açúcar foram atribuídos $20 \%$ dos pixels, ocorrendo erro de omissão, com atribuição de pixels das classes Pastagem, Solo nu e Vegetação nativa. Apenas 10\% dos pixels foram atribuídos corretamente à classe, havendo erro de comissão, com inclusão dos pixels das classes Pastagem, Solo nu e Vegetação nativa.

Foram atribuidos $77,42 \%$ dos pixels à classe Pastagem, ocorrendo erro de omissão, com atribuição dos pixels às classes Canade-açúcar e Vegetaçāo nativa. Foram atribuídos corretamente $66,67 \%$ dos pixels à classe, ocorrendo erro de comissão, com inclusão dos pixels das classes Solo nu, Cana-de-açúcar, Área urbana e Vegetação nativa.

Para a classe Reflorestamento foram atribuídos $100 \%$ dos pixels, porém ocorreu erro de comissão, apenas $27,27 \%$ dos pixels pertencem realmente à classe. Foram incluídos pixels da classe Vegetação nativa.

Para a classe Vegetação nativa foram atribuídos $42,11 \%$ dos pixels, ocorrendo erro de omissão, com atribuição dos pixels às classes Reflorestamento, Cana-de-açúcar e Pastagem. Foram atribuídos corretamente $50 \%$ dos pixels à classe, ocorrendo erro de comissão, com inclusão dos pixels das classes Pastagem, Cana-deaçúcar e Solo nu.

A classificação do algoritmo CLUSTER pode ser vista na Figura 5, apresentando-se semelhante à classificação do algoritmo MAXVER. 
Tabela 9. Matriz de confusão e Exatidão de acerto do algoritmo CLUSTER com filtro de mediana $3 \times 3$ representados em porcentagem.

\begin{tabular}{crrrrrrr}
\hline & S.N. & A.U. & C.A. & P. & R. & V.N. & Total \\
\hline S.N. & 15 & 1 & 1 & 0 & 0 & 0 & 17 \\
C.A. & 8 & 0 & 2 & 8 & 0 & 2 & 20 \\
P. & 15 & 2 & 6 & 48 & 0 & 1 & 72 \\
R. & 0 & 0 & 0 & 0 & 3 & 8 & 11 \\
V.N. & 1 & 0 & 1 & 6 & 0 & 8 & 16 \\
Total & 39 & 3 & 10 & 62 & 3 & 19 & 136 \\
E.G. & 55,88 & & & & & & \\
E.P. & 38,46 & 0,00 & 20,00 & 77,42 & 100,00 & 42,11 & \\
E.U. & 88,24 & 0,00 & 10,00 & 66,67 & 27,27 & 50,00 & \\
\hline
\end{tabular}

S N. = Solo nu; A.U.= Área urbana; C.A. = Cana-de-açúcar; $\mathrm{P}=$

Pastagem; $\mathrm{R}=$ Reflorestamento; V. $\mathrm{N}=$ Vegetação nativa; $\mathrm{E} . \mathrm{G}$. = Exatidão Geral; E.P. = Exatidão do produtor e E.U. = Exatidão do usuário. 


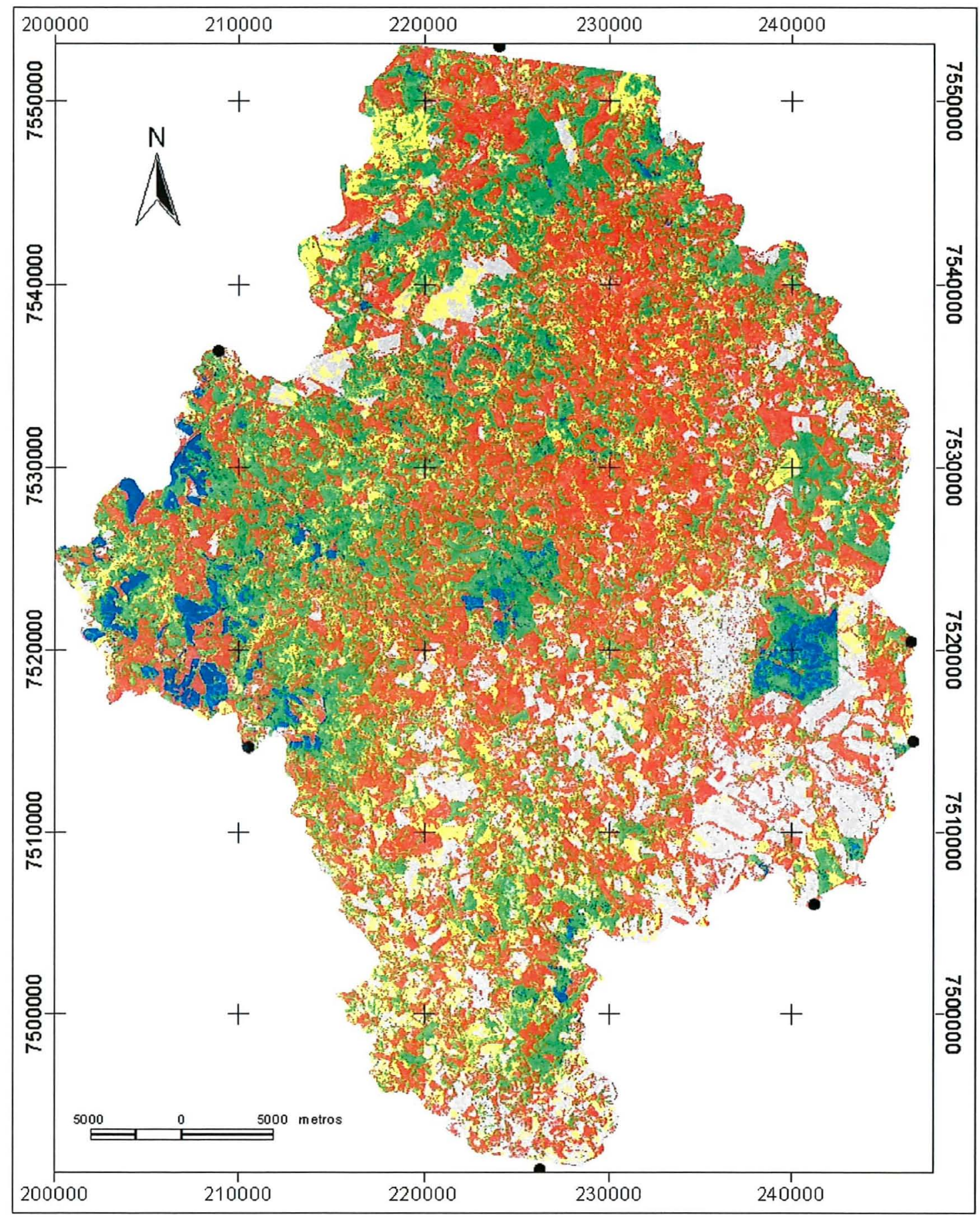

$\square$ Solo nu $\square$ Cana-de-açúcar $\square$ Pastagem $\square$ Reflorestamento $\square$ vegetaçăo nativa

Figura 5 - Reclassificação das 28 subclasses geradas no algoritmo CLUSTER. 


\section{MAXSET não filtrado}

Para o algoritmo MAXSET não filtrado a E.G., de acordo com a Tabela 10, foi de 71,32\%, com Kappa geral de 0,3303 considerada razoável de acordo com a Tabela 3. A Tabela 10 mostra que foram atribuídos $74,36 \%$ dos pixels à classe Solo nu, havendo erro de omissão, com atribuição dos pixels às classes de Pastagem, Área urbana e Vegetação nativa. Foram atribuídos corretamente $70,73 \%$ dos pixels à classe, ocorrendo erro de comissão, com inclusão de pixels das classes Pastagem, Área urbana e Cana-de-açúcar.

Não foram atribuídos pixels para a classe Área urbana.

Apenas $30 \%$ dos pixels foram atribuídos à classe Cana-deaçúcar. Houve erro por omissão, com atribuição dos pixels às classes Pastagem e Solo nu. Foram atribuídos corretamente 27,27\% dos pixels à classe, havendo erro de comissão, com inclusão dos pixels das classes Pastagem e Vegetação nativa.

Para a classe Pastagem foram atribuídos $72,58 \%$ dos pixels, havendo erro de omissão, com atribuição dos pixels às classes Solo nu, Cana-de-açúcar e Vegetação nativa. Foram atribuídos corretamente $77,59 \%$ dos pixels à classe, ocorrendo erro de comissão, com inclusão dos pixels das classes Solo nu, Cana-de-açúcar, Área urbana e Vegetação nativa.

Para a classe Reflorestamento foram atribuidos $100 \%$ dos pixels. Não houveram erros de omissão nem de comissão.

Foram atribuídos $89,47 \%$ dos pixels à classe Vegetação nativa, ocorrendo erro de omissão, com atribuição dos pixels às classes Cana-de-açúcar e Pastagem. Foram atribuídos corretamente 80,95\% dos pixels à classe, havendo erro de comissão, com inclusão dos pixels das classes Solo nu e Pastage 
Tabela 10. Matriz de confusão e Exatidão de acerto do algoritmo MAXSET representados em porcentagem.

\begin{tabular}{crrrrrrr}
\hline & S.N. & A.U. & C.A. & P. & R. & V.N. & Total \\
\hline S.N. & 29 & 2 & 2 & 8 & 0 & 0 & 41 \\
A.U. & 2 & 0 & 0 & 0 & 0 & 0 & 2 \\
C.A. & 0 & 0 & 3 & 7 & 0 & 1 & 11 \\
P. & 6 & 1 & 5 & 45 & 0 & 1 & 58 \\
R. & 0 & 0 & 0 & 0 & 3 & 0 & 3 \\
V.N. & 2 & 0 & 0 & 2 & 0 & 17 & 21 \\
Total & 39 & 3 & 10 & 62 & 3 & 19 & 136 \\
E.G. & 71,32 & & & & & & \\
E.P. & 74,36 & 0,00 & 30,00 & 72,58 & 100,00 & 89,47 & \\
E.U. & 70,73 & 0,00 & 27,27 & 77,59 & 100,00 & 80,95 & \\
\hline S N. Solo
\end{tabular}

S N. = Solo nu; A.U.= Área urbana; C.A. = Cana-de-açúcar; P = Pastagem; $\mathrm{R}=$ Reflorestamento; V.N = Vegetação nativa; E.G. = Exatidão Geral; E.P. = Exatidão do produtor e E.U. = Exatidão do usuário.

\section{MAXSET filtrado}

Para o algoritmo MAXSET filtrado a E.G., de acordo com a Tabela 11, foi de 50\%, com Kappa geral de 0,3046, considerado razoável de acordo com a Tabela 3 Para a classe Solo nu foram atribuídos $66,67 \%$ dos pixels, ocorrendo erro de omissão, com atribuição dos pixels às classes Vegetação nativa, Pastagem e Cana-de-açúcar. Foram atribuidos corretamente $78,79 \%$ dos pixels à classe, ocorrendo erro de comissão, com inclusão das classes Pastagem, Cana-de-açúcar e Área urbana. (Tabela 11).

Nenhum pixel foi atribuído à classe Área urbana.

Para a classe Cana-de-açúcar foram atribuídos $20 \%$ dos pixels, ocorrendo erro de omissão, com atribuição dos pixels às classes Pastagem, Vegetação nativa e Solo nu. Foram atribuídos corretamente $28,57 \%$ dos pixels à classe, ocorrendo erro de comissão, com inclusão de pixels das classes Pastagem, Vegetação nativa e Solo nu. 
Foram atribuídos $50 \%$ dos pixels à classe Pastagem, ocorrendo erro de omissão, com atribuição dos pixels às classes Vegetação nativa, Solo nu e Cana-de-açúcar. Foram atribuídos corretamente $64,58 \%$ dos pixels à classe, ocorrendo erro de comissão, com inclusão dos pixels das classes Vegetação nativa, Cana-de-açúcar e Solo nu.

Para a classe Reflorestamento foram atribuidos $100 \%$ dos pixels, não havendo erros por omissão e comissão.

Para a classe Vegetação nativa foram atribuídos $31,58 \%$ dos pixels, ocorrendo erro de omissão, com atribuição dos pixels às classes Pastagem, Solo nu e Cana-de-açúcar. Foram atribuídos corretamente $13,33 \%$ dos pixels à classe, ocorrendo erro de comissão, com inclusão dos pixels das classes Pastagem, Solo nu, Área urbana e Cana-de-açúcar.

O resultado da classificação do algoritmo MAXSET filtrado pode ser observado na Figura 6, onde existe uma fragmentação grande sem uma definição clara das classes quando se realiza uma comparação visual com a composição colorida. 
Tabela 11. Matriz de confusão e Exatidão de acerto do algoritmo MAXSET com filtro de mediana $3 \times 3$ representados em porcentagem.

\begin{tabular}{crrrrrrr}
\hline & S.N. & A.U. & C.A. & P. & R. & V.N. & Total \\
\hline S.N. & 26 & 1 & 2 & 4 & 0 & 0 & 33 \\
C.A. & 1 & 0 & 2 & 2 & 0 & 2 & 7 \\
P. & 2 & 0 & 4 & 31 & 0 & 11 & 48 \\
R. & 0 & 0 & 0 & 0 & 3 & 0 & 3 \\
V.N. & 10 & 2 & 2 & 25 & 0 & 6 & 45 \\
Total & 39 & 3 & 10 & 62 & 3 & 19 & 136 \\
E.G. & 50,00 & & & & & & \\
E.P. & 66,67 & 0,00 & 20,00 & 50,00 & 100,00 & 31,58 & \\
E.U. & 78,79 & 0,00 & 28,57 & 64,58 & 100,00 & 13,33 & \\
\hline
\end{tabular}

S N. = Solo nu; A.U.= Área urbana; C.A. = Cana-de-açúcar; P =

Pastagem; $\mathrm{R}=$ Reflorestamento; V.N = Vegetação nativa; E.G. = Exatidão Geral; E.P. = Exatidão do produtor e E.U. = Exatidão do usuário. 


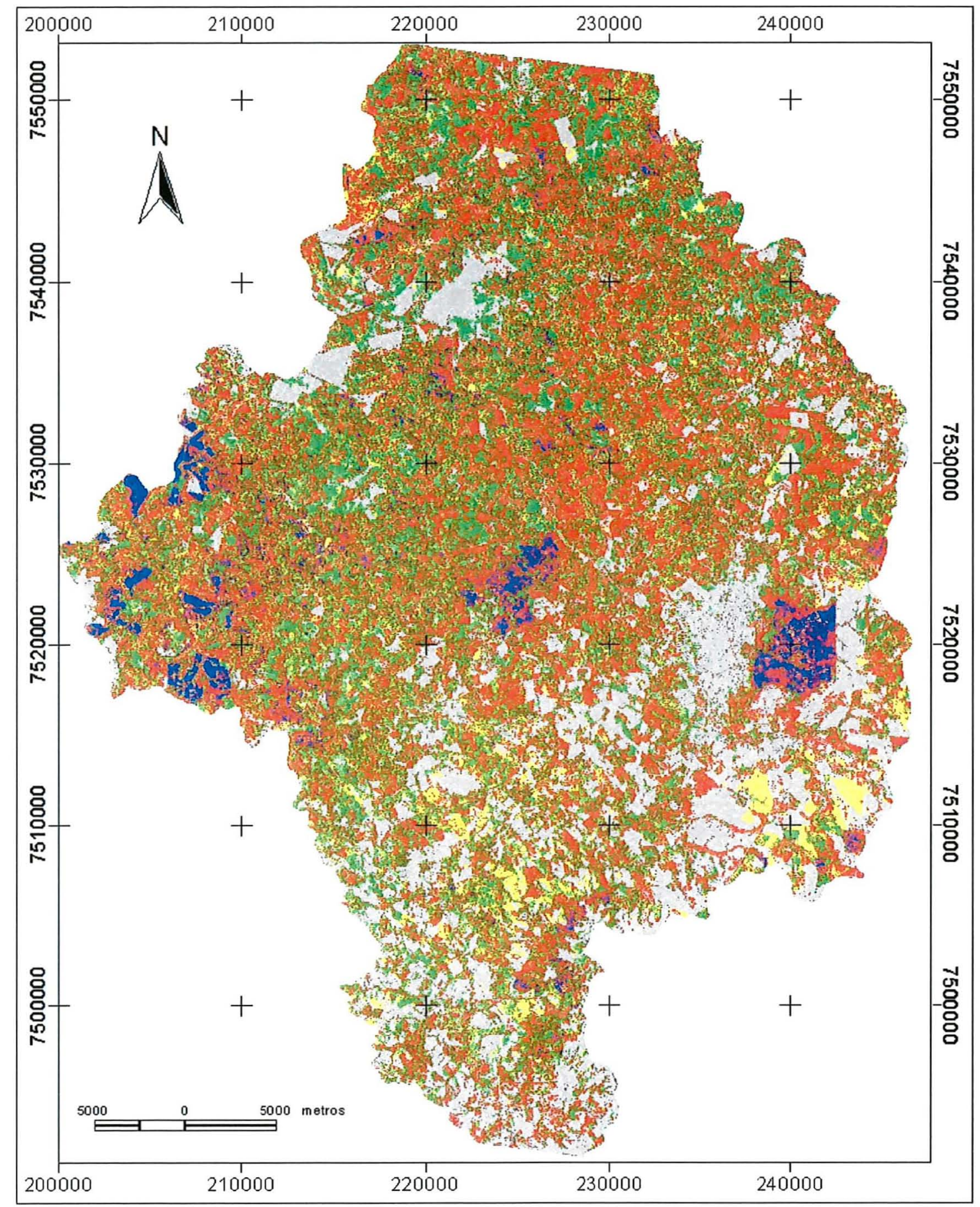

$\square$ Solo nu $\square$ Cana-de-açúcar $\square$ Pastagem $\square$ Reflorestamento $\square$ Vegetaçăo nativa

Figura 6 - Classificação obtida com a utilização do algoritmo MAXSET. 


\subsection{Análise das Matrizes de confusão e do Índice Kappa}

Pelas Tabelas 4 a 11 pode-se notar que nenhum dos algoritmos conseguiu classificar pixels da classe Área urbana, o que pode ser explicado pela heterogeneidade desses locais, onde a presença de praças, telhados, ruas, entre outras coberturas, que formam um mosaico das outras classes estabelecidas neste trabalho. Para a separação desta categoria as áreas poderiam ser isoladas manualmente pela digitalização de máscaras onde a classificação não seria realizada. Poderia-se utilizar também os sensores ativos, que podem separar as áreas construídas das demais áreas, corroborando com as observaçōes de Kuplich (1994), que confirma a complementaridade entre sensores passivos e ativos, principalmente para alvos urbanos.

Para a classe Solo nu os melhores algoritmos foram o MAXVER e MAXSET, apresentando valores próximos para a exatidão do produtor (Congalton, 1991) e "exatidão do usuário", indicando serem melhores que os algoritmos não-supervisionados, que apresentam maiores erros de omissão, sendo confundidos principalmente com a classe de Pastagem.

A classe Cana-de-açúcar não foi corretamente classificada por nenhum dos algoritmos. Devido a semelhança que a cultura da Cana-de-açúcar têm com as outras culturas e, devido a existência, em um mesmo período de vários estágios culturais, como cana adulta, recém cortada e em desenvolvimento, o que a torna espectralmente semelhante à Pastagem e Solo nu, como já foi descrito em estudo de Batista et al. (1978). A categoria Cana-de-açúcar foi encontrada freqüentemente fazendo limites com Pastagem e Vegetação nativa (Figura 8) e em várias situações de cobertura da terra (Figura 9). Devido às caracteristicas desta cultura, há necessidade de dados 
complementares para a delimitação desta categoria de cobertura, sendo necessário a utilização de dados históricos, bem como o conhecimento da região por parte do analista. Deve-se utilizar informações complementares ou imagens de outro periodo do ano, como IpollitiRamilo (1999) indica em seu trabalho. Pode ser utilizada a análise multitemporal, conforme Chen et al. (1986), para a redução das dúvidas decorrentes da utilização de um único período, visto que há alterações sazonais na cobertura da terra que ocorrem de maneira gradual ao longo do ano, como relatam Formaggio e Epiphanio (1990). Pixels foram atribuídos à classe Vegetação nativa, categoria que não guarda semelhanças espectrais com a classe Cana-de-açúcar, ou seja, os pixels não estão sendo espectralmente diferenciados, sugerindo a necessidade do uso de uma banda adicional para melhorar a capacidade de discriminação. O estudo de uma imagem unitemporal, no caso da cultura de Cana-de-açúcar, pode levar a resultados menores em área do que aqueles esperados, pois como se notou, várias áreas contendo Cana-de-açúcar recém colhida se comportavam como Solo nu.

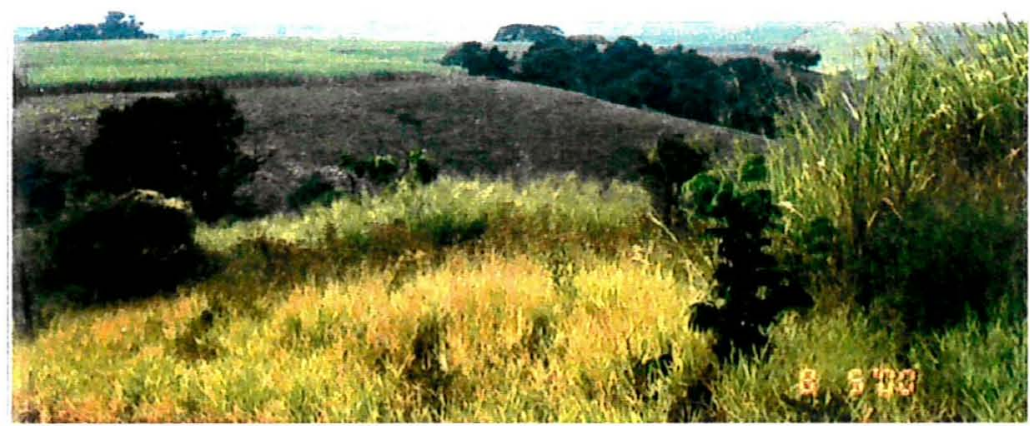

Figura 7 - Cana-de-açúcar em relevo suave ondulado, próximo a pastagens e remanescentes de vegetação nativa. 


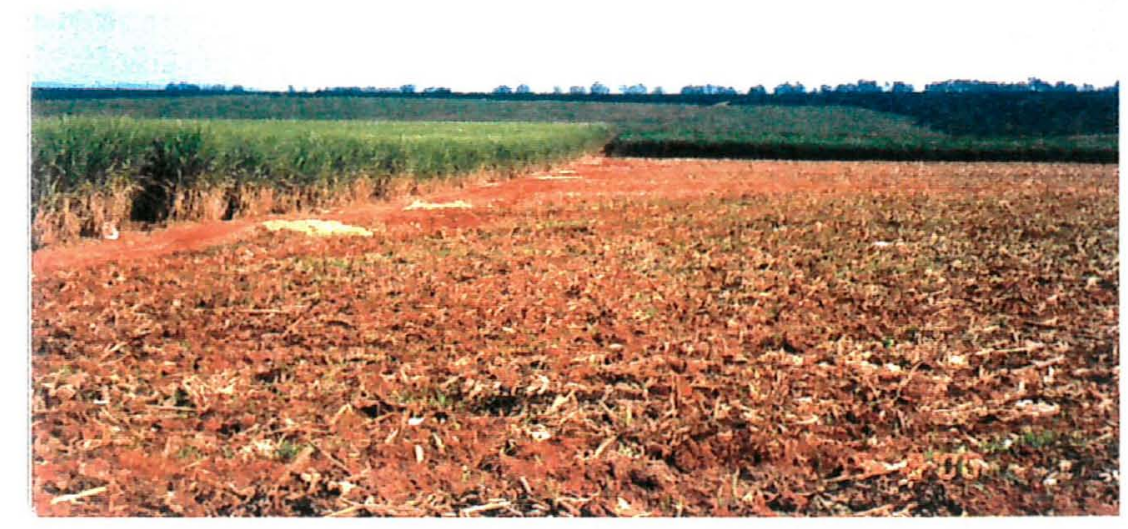

Figura 8 - Cana-de-açúcar em pé e recém cortada, na área de estudo evidenciando a existência de vários estados culturais.

Verificou-se que a classe Pastagem foi classificada corretamente pela maior parte dos algoritmos, sendo o algoritmo MAXSET aquele com o pior desempenho pois, pixels desta classe foram atribuídos à classe Vegetação nativa, que não tem características espectrais semelhantes, ocorrendo com todos os classificadores que não foram submetidos à filtragem. Para se evitar esse problema pode-se utilizar de mais uma banda espectral. Existe também a inclusão nesta categoria de pixels da categoria Solo nu. Neste caso podem ser encontrados pastos onde existe exposição do solo pela ocorrência de erosão ou manejo inadequado. A classe Pastagem tem ocorrência comum na área estudada e se apresentou em vários estados de manejo (Vettorazzi et al., 2000) e a Figura 10 mostra um pasto com sinais de erosão. 


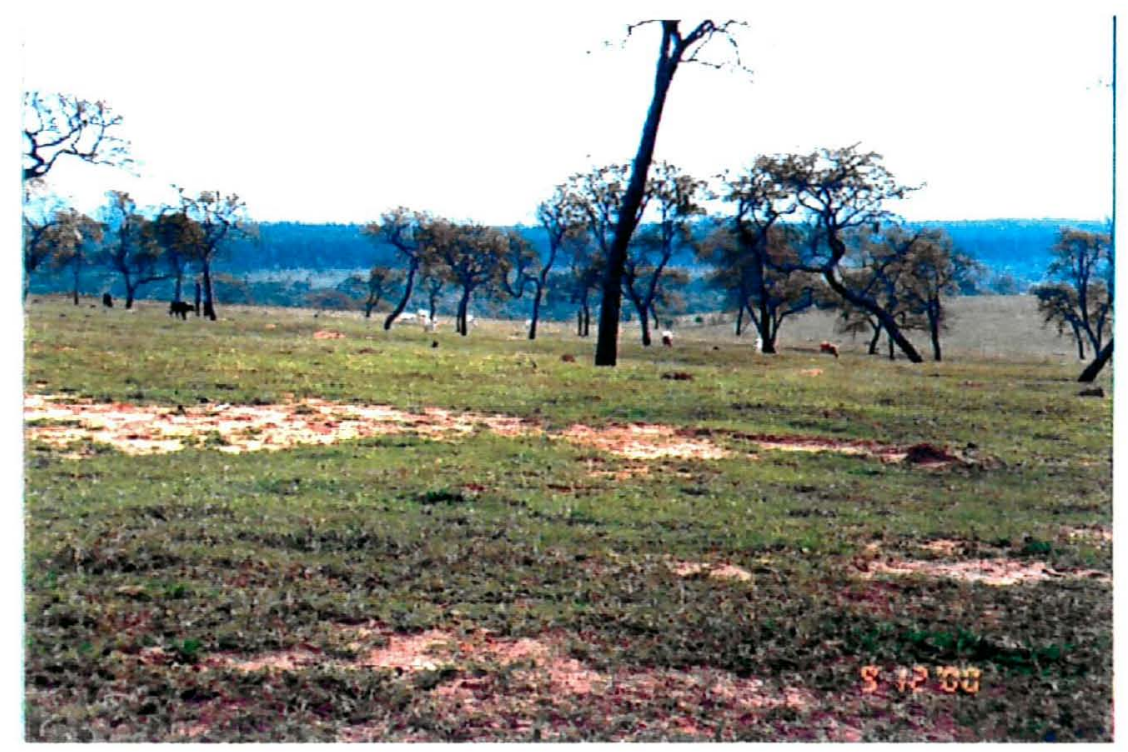

Figura 9 - Pastagem na área de estudo, próximo a uma área com reflorestamento, com sinais de erosão.

Em algumas situações observou-se a existência de plantios muito antigos de eucalipto, como os encontrados na área do Horto Florestal Navarro de Andrade, em Rio Claro, SP (Figura 11), onde o reflorestamento adquire a estrutura de floresta nativa, incluindo diversos estratos, o que dificultou a delimitação de áreas de treinamento na imagem, porém, apenas o algoritmo CLUSTER não classificou todos os pixels pertencentes à classe Reflorestamento, os demais algoritmos não apresentaram problemas para a diferenciação desta categoria, uma vez que ela é bastante homogênea e apresenta grande cobertura para o solo. 


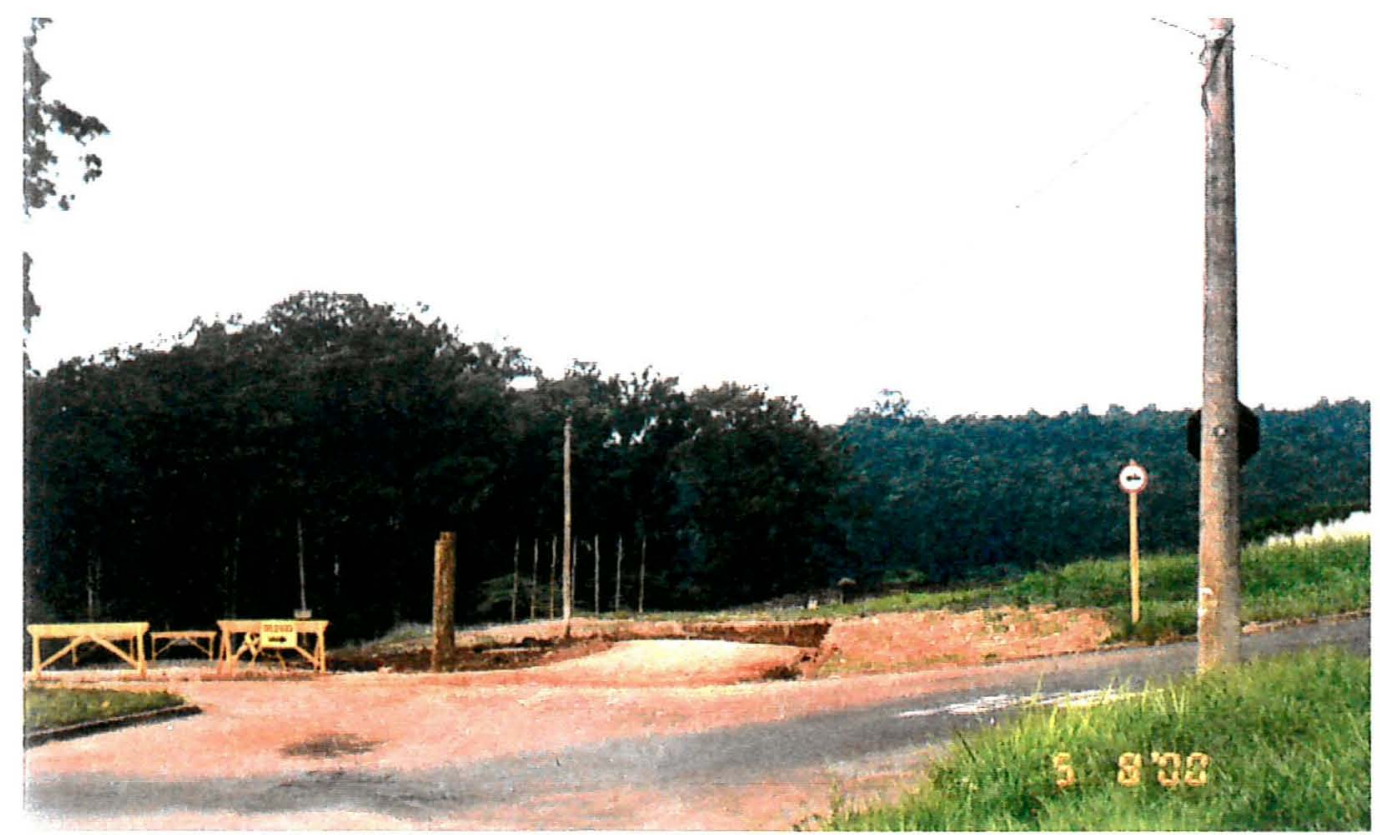

Figura 10 - Horto de Rio Claro: reflorestamentos antigos de eucalipto com estrutura de floresta nativa.

Os melhores resultados para a classe Vegetação nativa foram conseguidos pelos algoritmos MAXVER e ISOCLUST, respectivamente, apresentando poucos erros de comissão ou omissão, indicando que, apesar de haver poucos remanescentes, existia pouca variação espectral, permitindo uma boa classificação. O MAXSET foi o algoritmo que obteve os piores resultados para esta categoria uma vez que houveram muitos erros de comissão e omissão, ainda que utilizando as mesmas amostras de treinamento que as utilizadas pelo MAXVER. 


\subsection{Análise da Classificação Digital}

Dentre os algoritmos utilizados, o MAXVER foi o que apresentou os maiores valores para o indice Kappa geral, sendo de 0,601 (filtrado) e 0,5849 (não filtrado), sendo considerado "muito bom" e "bom", respectivamente, de acordo com a Tabela 3. Houve, porém, uma variação significativa nos valores de E.G. para a classificação supervisionada.

O algoritmo ISOCLUST apresentou os melhores valores de Kappa geral para a classificação filtrada $(0,4973)$ e não filtrada $(0,5066)$, sendo considerado "bom", de acordo com a Tabela 3, apresentando pequena variação para E.G.

O CLUSTER é um algoritmo bastante simples, necessitando apenas de uma composição colorida e dos picos do histograma da imagem para a definição de classes de acordo com a solicitação, porém, de acordo com o indice Kappa geral (Tabela 3), foi considerado "razoável" e apresentou valores de E.G. com pouca variação.

O algoritmo MAXSET apresentou o menor valor de indice Kappa geral (Tabela 3) para as classificações filtrada $(0,3046)$ e não filtrada $(0,3303)$, sendo considerada "razoável" e apresentou também variação significativa para os valores de E.G., à semelhança do algoritmo MAXVER.

Nota-se que os valores de E.G. apresentaram maior variação para os algoritmos de classificação que utilizaram amostras de treinamento. Este fato pode ser visto ao observar-se os valores de E.G. para os algoritmos que receberam a filtragem. 
As amostras de treinamento não foram homogêneas devido a similaridade entre as categorias delimitadas, o que alterou o resultado das classificações que as utilizaram (Crosta, 1992).

A filtragem não afetou de modo significativo o resultado da classificação dos algoritmos ISOCLUST e CLUSTER, assim sendo, podese afirmar que ela não interfere substancialmente no resultado de uma classificação.

Tabela 12. Índice Kappa Geral das imagens filtradas

\begin{tabular}{lc}
\hline FILTRO DE MEDIANA & KAPPA \\
\hline MAXVER & 0,601 \\
CLUSTER & 0,3641 \\
MAXSET & 0,3046 \\
ISOCLUST & 0,4973 \\
\hline
\end{tabular}

Tabela 13. Índice Kappa Geral das imagens não filtradas

\begin{tabular}{lc}
\hline SEM FILTRAGEM & KAPPA \\
\hline MAXVER & 0,5849 \\
CLUSTER & 0,3529 \\
MAXSET & 0,3303 \\
ISOCLUST & 0,5066 \\
\hline
\end{tabular}


A classificação MAXVER necessita de amostras de treinamento que são visualizadas e demarcadas pelo analista. Ao utilizar uma composição colorida pode-se melhorar a visualização pelo ajuste de contraste ou atribuição de cores às bandas. Porém, com as bandas utilizadas, o contraste entre as classes não foi muito visivel. A utilização de bandas adicionais às utilizadas, principalmente a banda 4 do SPOT 4, poderia melhorar a delimitação das classes e aumentar a Exatidão Geral do algoritmo MAXVER. Como é mostrado na Figura 12, a delimitação de áreas homogêneas correspondentes à áreas de Cana-deaçúcar e Solo nu, é bem mais simples do que aquelas realizadas em áreas com formato irregular em terreno mais acidentado (Figura 13) que demandaram um tempo maior para sua delimitação. 


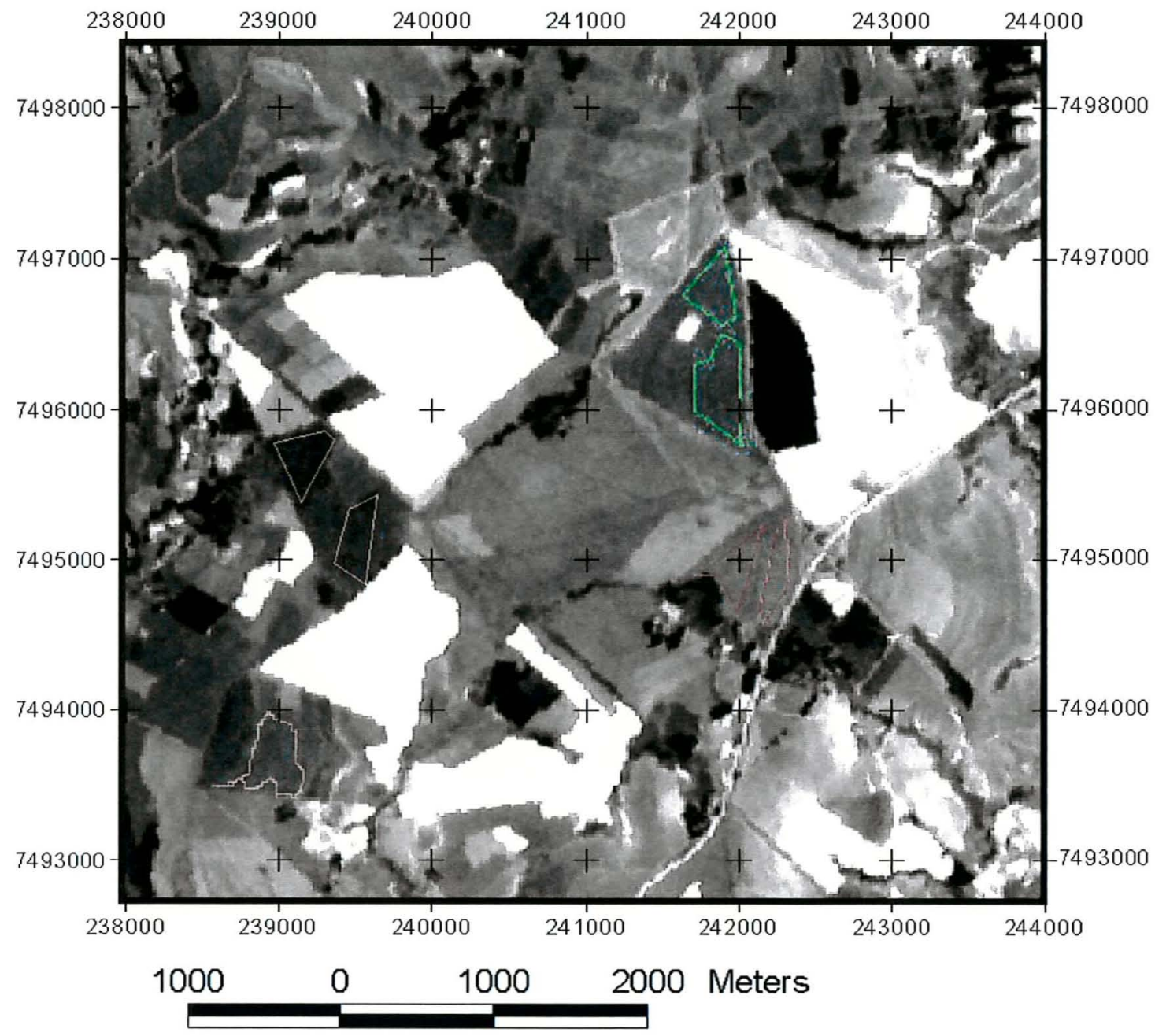

Figura 11 - Áreas de treinamento homogêneas com formato regular. 


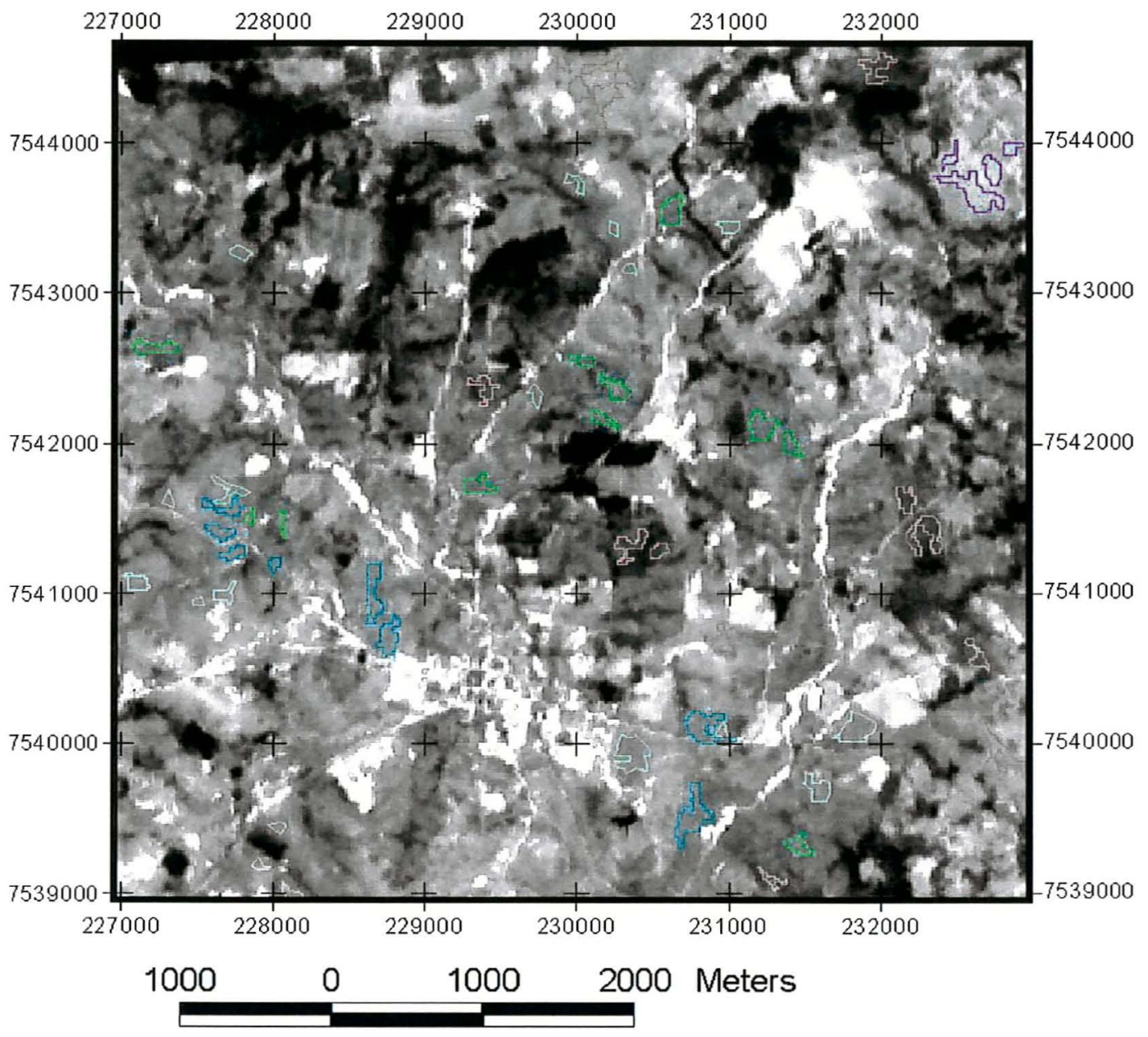

Figura 12 - Áreas de treinamento de tamanho reduzido e formato irregular. 
O algoritmo ISOCLUST mostrou-se simples e não dependente do usuário, podendo ser repetido em outras épocas do ano para o monitoramento de uma área, sendo o algoritmo não supervisionado mais adotado, concordando com Jusoff e Manaf (1995) e Novo (1992), o que torna o trabalho menos complexo e sem a necessidade de Amostras de Treinamento. O ISOCLUST foi o classificador não supervisionado com melhores resultados para as classes de Solo nu, Pastagem e Reflorestamento. A maior parte da Vegetação nativa foi incluída, porém, houve muitos erros de comissão, principalmente com a inclusão da classe Pastagem, indicando neste caso, que a delimitação de amostras de treinamento desta classe para o MAXVER foi mais eficiente. Embora a classificação supervisionada não filtrada tenha obtido melhores resultados dos valores de Kappa geral, pode-se observar que os resultados da exatidão global são menores que os obtidos pelo algoritmo ISOCLUST. No fluxograma de atividades (Figura 14) percebe-se que, para a classificação não supervisionada, duas fases não existem, que são delimitação de amostras de treinamento e confirmação das classes em campo, agilizando o processo de interpretação.

$\mathrm{Na}$ situação da área de estudo o resultado poderia ser melhorado pela aplicação da classificação híbrida, concordando com Caldeira (1994), Congalton (1991) e Novo (1992). O classificador ISOCLUST seria usado para criar áreas homogêneas na imagem, onde podem ser delimitadas com mais facilidade as áreas de treinamento para a classificação supervisionada, uma vez que os limites de classes são mais visiveis (Crosta, 1992).

De maneira geral as categorias Reflorestamento, Pastagem e Solo nu foram bem classificados pela maioria dos algoritmos. A categoria Vegetação nativa foi bem classificada pelo 
MAXVER, ISOCLUST e MAXSET. A categoria Cana-de-açúcar não foi bem reconhecida por nenhum dos algoritmos e a categoria Área urbana não foi classificada por não representar uma classe única.

A data de passagem da imagem coincide com uma grande exposição do solo, tornando as áreas com culturas anuais dificeis de divisar, podendo ocorrer erros com as áreas de treinamento, o que concorda com Chen (1988).

A versão do "software" de processamento de imagens IDRISI utilizada para a classificação não supervisionada mostrou-se adequada para utilização na área de estudo, no entanto, as ferramentas para manipulação de vetores são inadequadas para grandes volumes de dados.

Para a classificação supervisionada utilizou-se o "software" ENVI, que permite uma visualização melhor de composições coloridas, representando um número maior de cores. O ENVI tem mais recursos para a manipulação de dados vetoriais, o que torna a tarefa de delimitação de áreas de treinamento mais simples e rápida.

Neste trabalho, foi utilizada a imagem do SPOT 4 do início da primavera, época em que ocorre a colheita de inverno. Este periodo retrata uma situação particular do ano, não representando o que ocorre ao longo do ano, portanto, em alguns tipos de cobertura existe uma variação sazonal que é o exemplo da agricultura. A diferenciação de algumas culturas necessita de uma avaliação multitemporal para se conhecer melhor a cobertura da terra em uma determinada região (Ipolliti-Ramilo, 1999). Da mesma maneira, considerar apenas parte do espectro para o estudo limita a capacidade de diferenciação de alvos, como por exemplo as áreas urbanas que são evidenciadas com imagens de Radar (Kuplich, 1994). 
A utilização da imagem do SPOT poderia ser substituída ou não pela imagem do LANDSAT TM, não existindo diferença significativa na comparação dessas duas imagens (San Miguel Ayánz e Biging ,1997).

Finalmente, pode-se observar que neste trabalho tornou-se dificil a sua comparação com os autores citados na revisão, visto que, em sua maioria, utilizam as bandas 2,3 e 4 do SPOT ou 3,4 e 5 do LANDSAT e em nosso caso, utilizou-se as bandas 1, 2 e 3 da imagem mais recente $(22 / 09 / 1999)$ do SPOT 4.

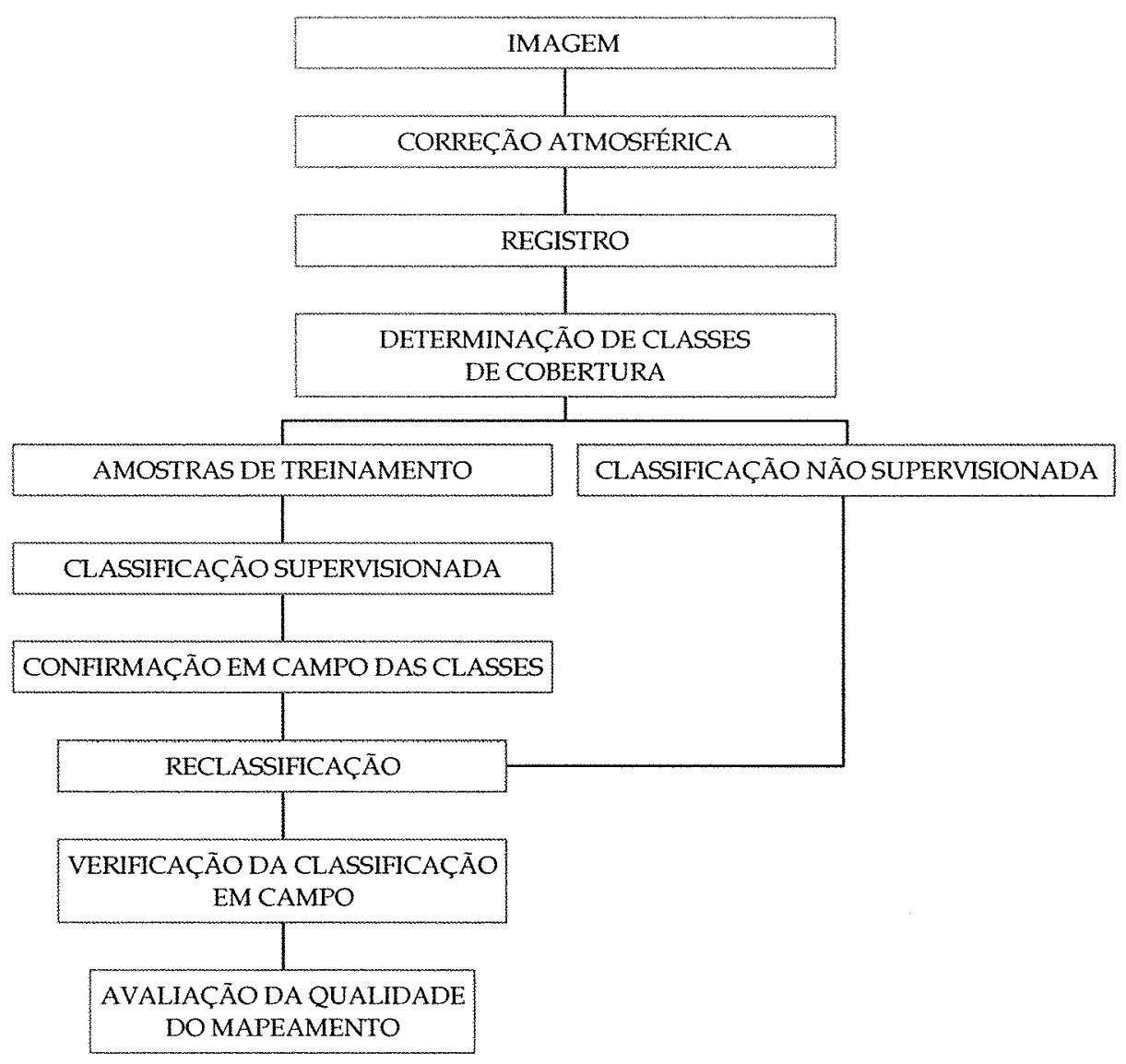

Figura 13 - Métodos dos procedimentos adotados na classificação digital 


\section{CONCLUSÕES}

O algoritmo MAXVER foi o que apresentou melhor valor de Kappa geral, porém, os valores da exatidão geral entre o MAXVER filtrado e não filtrado variaram muito.

O algoritmo ISOCLUST não supervisionado foi o que apresentou os melhores valores para o indice Kappa geral e pequena variação entre os valores de exatidão geral na classificação filtrada e não filtrada, podendo ser utilizado como substituto da classificação MAXVER para as condições estudadas.

O algoritmo CLUSTER apresentou baixos valores para o indice Kappa geral e pequena variação para exatidão geral.

$\mathrm{O}$ algoritmo MAXSET apresentou os valores mais baixos para o indice Kappa geral e também apresentou variação significativa para a exatidão geral, entre MAXSET filtrado e não filtrado.

As amostras de treinamento afetaram os valores de exatidão geral para a classificação supervisionada, indicando que a delimitação nas condições da imagem utilizada, não obteve suficiente número de amostras homogêneas, embora houvesse o cuidado com a delimitação, muitos limites de classe não foram claramente visiveis.

A imagem unitemporal retrata apenas um periodo, não apresentando todas as variações de cobertura da terra que ocorrem ao longo do ano. 


\section{REFERÊNCIAS BIBLIOGRÁFICAS}

ALVES, D.S.; MOREIRA, J.C.; KALIL, E.M.; SOARES, J.V.; FERNANDEZ, O.; ALMEIDA, S.; ORTIZ, J.D.; AMARAL, S. Mapeamento do uso do solo em Rondônia utilizando técnicas de segmentação e classificação de imagens TM. (compact disk) In: SIMPÓSIO BRASILEIRO DE SENSORIAMENTO REMOTO, 8., Salvador, 1996. Anais. São José dos Campos: Instituto Nacional de Pesquisas Espaciais, 1996.

ALVES, D.S.; PEREIRA, J.L.G.; SOUSA, C.L.; SOARES, J.V.; MOREIRA, J.C.; ORTIZ, J.; SHIMABUKURO, Y.E.; YAMAGUCHI, F.. Análise comparativa de técnicas de classificação de imagens do sensor Landsat/TM para caracterização de áreas desflorestadas. (compact disk) In: SIMPÓSIO BRASILEIRO DE SENSORIAMENTO REMOTO, 9., Santos, 1998. Anais. São José dos Campos: Instituto Nacional de Pesquisas Espaciais, 1998.

ASSUNÇÃO, G.V.; DUARTE, V. Avaliação de áreas preparadas para plantio (SOLONU) utilizando dados do satélite LANDSAT. São José dos Campos, 1983. 75p.. Dissertação (Mestrado) - Instituto Nacional de Pesquisas Espaciais. 
BALL, G.H.; HALL, D.J. A novel method of data analysis and pattern classification. Menlo Park: Stanford Research Institute, 1965. $35 \mathrm{p}$.

BATISTA, G.T.; MENDONÇA, F.J.; LEE, D.C.L.; TARDIN, A.T.; CHEN, S.C.; NOVAES, R.A. Uso de sensores remotos a bordo de satélite e aeronave na identificação e avaliação de áreas de culturas para fins de previsão de safras. São José dos Campos: Instituto Nacional de Pesquisas Espaciais, 1978. 46p.

BISHOP, Y.M.M.; FIENBERG, S.E.; HOLLAND, P.W. Measures of association and agreement. In: BISHOP, Y.M.M.; FIENBERG, S.E.; HOLLAND, P.W. Discrete multivariate analysis: theory and practice. Cambridge: MIT, 1975. cap.11, p.373-400.

BRINO, W.C. Contribuição à definição climática da Bacia do Corumbatai e adjacências (SP), dando ênfase à caracterização dos tipos de tempo. Rio Claro, 1973. 173p. Tese (Doutorado) Faculdade de Filosofia, Ciências e Letras, Universidade Estadual Paulista

BRITES, R.S.; SOARES, V.P.; RIBEIRO, C.A.A.S. Efeitos da estratégia de amostragem na exatidão reportada pelo indice Kappa na classificação de imagens orbitais. (compact disk) In: SIMPÓSIO BRASILEIRO DE SENSORIAMENTO REMOTO, 8., Salvador, BA, 1996. Anais. São José dos Campos: Instituto Nacional de Pesquisas Espaciais, 1996. 
CAETANO, M.; NAVARRO, A.; SANTOS, J.P. Improving urban areas mapping with satelite imagery by contextual analysis and integration of a road network map. In: ANNUAL CONFERENCE AND EXHIBITION OF THE REMOTE SENSING SOCIETY, 23., Bulmershe Court, 1997. Anais. Nottingham: Arrowhead Reading, 1997. p.106111 .

CALDEIRA, H.S. Classificação temática de áreas litorâneas: uma contribuição metodológica. São José dos Campos, 1994. 133p. Dissertação (Mestrado) - Instituto Nacional de Pesquisas Espaciais.

CAMPBELL, J.B.. History and scope of remote sensing. In: CAMPBELL, J.B. Introduction to remote sensing. 3.ed. London: The Guilford Press, 1996. cap.1, p.1-11.

CHEN, S.C. Separabilidade espectral de culturas de verão a partir de dados digitais do satélite TM-Landsat. In: SIMPÓSIO BRASILEIRO DE SENSORIAMENTO REMOTO, 5., Natal, 1988. Anais, São José dos Campos: Instituto Nacional de Pesquisas Espaciais, 1988. v.1, p.211-216.

CHEN, S.C.; BATISTA, G.T.; TARDIN, A.T. TM band combination for crop discrimination. São José dos Campos: Instituto Nacional de Pesquisas Espaciais, 1986. 6p.

CONGALTON, R.G.; MEAD, R.A. A quantitative method to test for consistency and correctness in photointerpretation.

Photogrammetric Engineering and Remote Sensing, v.49, n.1, p.69-74, 1983. 
CONGALTON, R.G. A review of assessing the accuracy of classifications of remotely sensed data. Remote Sensing of Environment, v.37, n.1, p.35-46, 1991.

CROSTA, A.P. Processamento digital de imagens de sensoriamento remoto. Campinas: UNICAMP, 1992. 170p.

CZAPLEWSKI, R.L. Strategies for global monitoring of tropical forests. New Orleans: USDA, Forest Service, Southeastern Forest Experiment Station, 1994. 84p. (General Technical Report SO, 113)

DIAS, L.A.V.; PONZONI, F.J.; OLIVEIRA, E.A. Uso de modelo digital de elevação para corrigir o efeito do relevo em reflorestamento de Eucalyptus em regiōes montanhosas. São José dos Campos: Instituto Nacional de Pesquisas Espaciais, 1988. 5p. (Publicação INPE-4763-PRE/1432)

DUTRA, L.V.; SOUZA, R.C.M. de; II, F.A.M.; MOREIRA, J.C. Análise automática de imagens multiespectrais. São José dos Campos, Instituto Nacional de Pesquisas Espaciais, 1981. 31p.

EASTMAN, J. R. IDRISI for windows version 2.00: user's guide. Worcester: Clark University, Graduate School of Geography, 1997. $331 \mathrm{p}$. 
FERREIRA, J.C.G. Avaliação e integração de dados LANDSAT-TM, geofisicos e geológicos através de técnicas de processamento digital de imagem e Sistema de Informações Geográficas. São José dos Campos, 1992. 184p. Dissertação (Mestrado) - Instituto Nacional de Pesquisas Espaciais.

FONSECA, F.P. Avaliação do uso de processamento pigital de imagens de satélite em geografia, a partir de um teste no Núcleo Picinguaba (Parque Estadual da Serra do Mar), Ubatuba, S.P. São Paulo, 1995. 99p. Dissertação (Mestrado), Faculdade de Filosofia, Ciências e Letras Humanas - Universidade de São Paulo.

FORMAGGIO, A.R.; EPIPHANIO, J.C.N. Caracteristicas espectrais de culturas e rendimento agricola. São José dos Campos: Instituto Nacional de Pesquisas Espaciais, 1990. 166p.

HERNÁNDEZ-FILHO, P.; PONZONI, F.J.; PEREIRA, M.N. Mapeamento da fitofisionomia e do uso da terra de parte da Bacia do Alto Taquari mediante o uso de imagens TM/LANDSAT e HRV/SPOT. São José dos Campos: Instituto Nacional de Pesquisas Espaciais, 1998. p.1755-1762.

INSTITUTO BRASILEIRO DE GEOGRAFIA E ESTATISTICA. Carta do Brasil: Araras. Rio de Janeiro, 1969. Folha SF-23-M-II-3, Escala 1:50.000.

INSTITUTO BRASILEIRO DE GEOGRAFIA E ESTATÍSTICA. Carta do Brasil: Itirapina. Rio de Janeiro, 1969. Folha SF-23-M-I-3, Escala $1: 50.000$. 
INSTITUTO BRASILEIRO DE GEOGRAFIA E ESTATÍSTICA. Carta do Brasil: Limeira. Rio de Janeiro, 1969. Folha SF-23-M-IV-1, Escala 1:50.000.

INSTITUTO BRASILEIRO DE GEOGRAFIA E ESTATÍsTICA. Carta do Brasil. Piracicaba. Rio de Janeiro, 1969. Folha SF-23-Y-A-IV-2, Escala 1:50.000.

INSTITUTO BRASILEIRO DE GEOGRAFIA E ESTATÍSTICA. Carta do Brasil: Rio Claro. Rio de Janeiro, 1969. Folha SF-23-M-I-4, Escala 1:50.000.

INSTITUTO BRASILEIRO DE GEOGRAFIA E ESTATISTICA. Carta do Brasil: São Pedro. Rio de Janeiro, 1969. Folha SF-23-M-III-1, Escala 1:50.000.

INSTITUTO BRASILEIRO DE GEOGRAFIA E ESTATÍSTICA. Carta do Brasil: Corumbatai. Rio de Janeiro, 1971. Folha SF-23-Y-A-I-2, Escala 1:50.000.

INSTITUTO BRASILEIRO DE GEOGRAFIA E ESTATÍSTICA. Carta do Brasil: Leme. Rio de Janeiro, 1971. Folha SF-23-Y-A-II-1, Escala 1:50.000.

INSTITUTO DE PESQUISAS TECNOLÓGICAS DO ESTADO DE SÃO PAULO. Mapa geológico do Estado de São Paulo. São Paulo. São Paulo: Divisão de Minas e Geologia Aplicada, 1981a. v.1, 94p. 
INSTITUTO DE PESQUISAS TECNOLÓGICAS DO ESTADO DE SÃO PAULO. Mapa geomorfológico do Estado de São Paulo. São Paulo: Divisão de Minas e Geologia Aplicada, 1981b. v.1, 94p.

INSTITUTO GEOGRÁFICO E CARTOGRÁFICO. Plano Cartográfico do Estado de São Paulo: carta de utilização do solo do Estado de São Paulo, Campinas. São Paulo: Abril, 1980. Folha SF 23 Y A, Escala 1: 250.000 .

IPOLLITI-RAMILO, G.A. Imagens TM/LANDSAT-5 da época de préplantio para a previsão da área de cultura de verão. São José dos Campos, 1999. 183p. Dissertação (Mestrado) - Instituto Nacional de Pesquisas Espaciais.

JUSOFF, K.; MANAF, M. Satellite remote-sensing of deforestation in the Sungai-Buloh-Forest-Reserv, Peninsular Malaysia. International Journal of Remote Sensing, v. 16, n. 11, p.1981-1997, 1995.

KUPLICH, T.M. Estudo da complementaridade de imagens óticas (LANDSAT/TM) e de radar (ERS-1/SAR) na discriminação temática de uso da terra. São José dos Campos, 1994. 108p. Dissertação (Mestrado) - Instituto Nacional de Pesquisas Espaciais.

LACHOWSKI, H.M.; WIRTH, T.;MAUS, P.; AVERS, P. Remote sensing and GIS: their role in ecosystem management. Journal of Forestry, v.92, n.8, p.39-40, Aug. 1994.

LANDIS, J.R.; KOCH, G.G. The measurement of observer agreement for categorical data. Biometrics, v.33, p.159-174, Mar. 1977. 
LILLESAND, T.M.; KIEFER, R.W. Digital image processing. In: LILLESAND, T.M.; KIEFER, R.W. Remote sensing and image interpretation. New York: John Wiley, 1994. cap. 7, p.524-647.

MEDEIROS, A.M.P.; RUDORFF, B.F.T.; SHIMABUKURO, Y.E. Imagens Landsat na estimativa de áreas de cana-de-açúcar, milho e soja. (compact disk) In: SIMPÓSIO BRASILEIRO DE SENSORIAMENTO REMOTO, 8., Salvador, 1996. Anais. São José dos Campos: Instituto Nacional de Pesquisas Espaciais, 1996.

NASCIMENTO, P.S.R.; ALMEIDA FILHO, R. Utilização da técnica de segmentação em Imagens TM/Landsat visando otimizar a técnica de interpretação visual. (compact disk) In: SIMPÓSIO BRASILEIRO DE SENSORIAMENTO REMOTO, Salvador, 1996. Anais. São José dos Campos: Instituto Nacional de Pesquisas Espaciais, 1996.

NOVO, E.M.L.M. Comportamento espectral de alvos. In: NOVO, E.M.L.M. Sensoriamento remoto: principios e aplicações. 2.ed. São Paulo: Edgard Blücher, 1992. cap. 6, p.180-204.

OLIVEIRA, J.B.; MENK, J.R.; ROTTA, C.L. Levantamento pedológico semi-detalhado do Estado de São Paulo: quadricula de São Carlos. Campinas: Instituto Agronômico de Campinas, 1979. Escala $1: 100.000$.

OLIVEIRA, J.B.; PRADO, H. Levantamento pedológico semidetalhado do Estado de São Paulo: quadricula de Piracicaba. Campinas: Instituto Agronômico de Campinas, 1989. Escala 1:100.000. 
PONZONI, J.F.; ALMEIDA, E.S. A estimativa do parâmetro Kappa (k) da análise multivariada discreta no contexto de um SIG. (compact disk) In: SIMPÓSIO BRASILEIRO DE SENSORIAMENTO REMOTO, 8., Salvador, 1996. Anais. 1996.

QUINTANILHA, J.A. Processamento de imagens digitais In: SIMPÓSIO BRASILEIRO DE GEOPROCESSAMENTO, São Paulo, 1990. Anais. São Paulo: Universidade de São Paulo, Escola Politécnica, 1990. p.37-48.

SAN MIGUEL-AYANZ, J.; BIGING, G.S. Comparison of single-stage and multi-stage classification approaches for cover type mapping with TM and SPOT data. Remote Sensing of Environment, v.59. p.92-104, 1997.

SANTOS, J.R. Utilização de imagens orbitais como forma adequada no controle de áreas de preservação. São José dos Campos: Instituto Nacional de Pesquisas Espaciais, 1982. 18p. (Publicação INPE-2064-RPE/306)

SWAIN, P.H.; DAVIS, S.M. Fundamentals of pattern recognition in remote sensing. In: SWAIN, P.H.; DAVIS, S.N. Remote sensing: the quantitative approach. New York: McGraw-Hill, 1978. cap. 3. p.136185.

THOMPSON, M.W.; WHITEHEAD, K. An overview of remote sensing in Forestry and related activities; its potential application in South Africa. South African Forestry Journal, n.161, p.59-69. 1992. 
VETTORAZZI, C.A.; VIANA, V.M.; VALENTE, R. de O.A.; MENDES, J.C.T.; FERRAZ, D.J.; ZOTELLI, M.J. Geoprocessamento no estudo da paisagem da bacia do rio Corumbataí, visando à atividade de recuperação florestal. (compact disk) In: FÓRUM DE DEBATES ECOLOGIA DA PAISAGEM E PLANEJAMENTO AMBIENTAL, 1., RioClaro, 2000. Anais. Rio Claro: Sociedade de Ecologia do Brasil.

VOGELMANN, J.E.; SOHL, T.; HOWARD, S.M. Regional characterization of land cover using multiple. Photogrammetric Engineering and Remote Sensing. v.64, n.1, p.45-57, Jan. 1998.

ZAVATINI, J.A.; CANO, H. Variaçōes no ritmo pluvial na bacia do rio Corumbataí - SP. Boletim de Geografia Teorética, n.23, p.215$240,1993$. 